\title{
This Project Stinks
}

by

\section{Katelyn Lucas}

B. Arch. St.

\author{
A thesis submitted to \\ The Faculty of Graduate Studies \\ in partial fulfillment of \\ the requirements for the degree of
}

\section{Master of Architecture}

Azrieli School of Architecture and Urbanism

Carleton University

Ottawa, Ontario

September 21, 2010

Copyright $@ 2010$ Katelyn Lucas 
Library and Archives

Canada

Published Heritage

Branch

395 Wellington Street Ottawa ON K1A ON4

Canada
Bibliothèque et

Archives Canada

Direction du

Patrimoine de l'édition

395 , rue Wellington

Ottawa ON K1A ON4

Canada
Your file Votre reférence ISBN:978-0-494-71729-5

Ourfile Notre référence ISBN: 978-0-494-71729-5
NOTICE:

The author has granted a nonexclusive license allowing Library and Archives Canada to reproduce, publish, archive, preserve, conserve, communicate to the public by telecommunication or on the Internet, loan, distribute and sell theses worldwide, for commercial or noncommercial purposes, in microform, paper, electronic and/or any other formats.

The author retains copyright ownership and moral rights in this thesis. Neither the thesis nor substantial extracts from it may be printed or otherwise reproduced without the author's permission.
AVIS:

L'auteur a accordé une licence non exclusive permettant à la Bibliothèque et Archives Canada de reproduire, publier, archiver, sauvegarder, conserver, transmettre au public par télécommunication ou par l'Internet, prêter, distribuer et vendre des thèses partout dans le monde, à des fins commerciales ou autres, sur support microforme, papier, électronique et/ou autres formats.

L'auteur conserve la propriété du droit d'auteur et des droits moraux qui protège cette thèse. $\mathrm{Ni}$ la thèse ni des extraits substantiels de celle-ci ne doivent être imprimés ou autrement reproduits sans son autorisation.
In compliance with the Canadian Privacy Act some supporting forms may have been removed from this thesis.

While these forms may be included in the document page count, their removal does not represent any loss of content from the thesis.
Conformément à la loi canadienne sur la protection de la vie privée, quelques formulaires secondaires ont été enlevés de cette thèse.

Bien que ces formulaires aient inclus dans la pagination, il n'y aura aucun contenu manquant. 


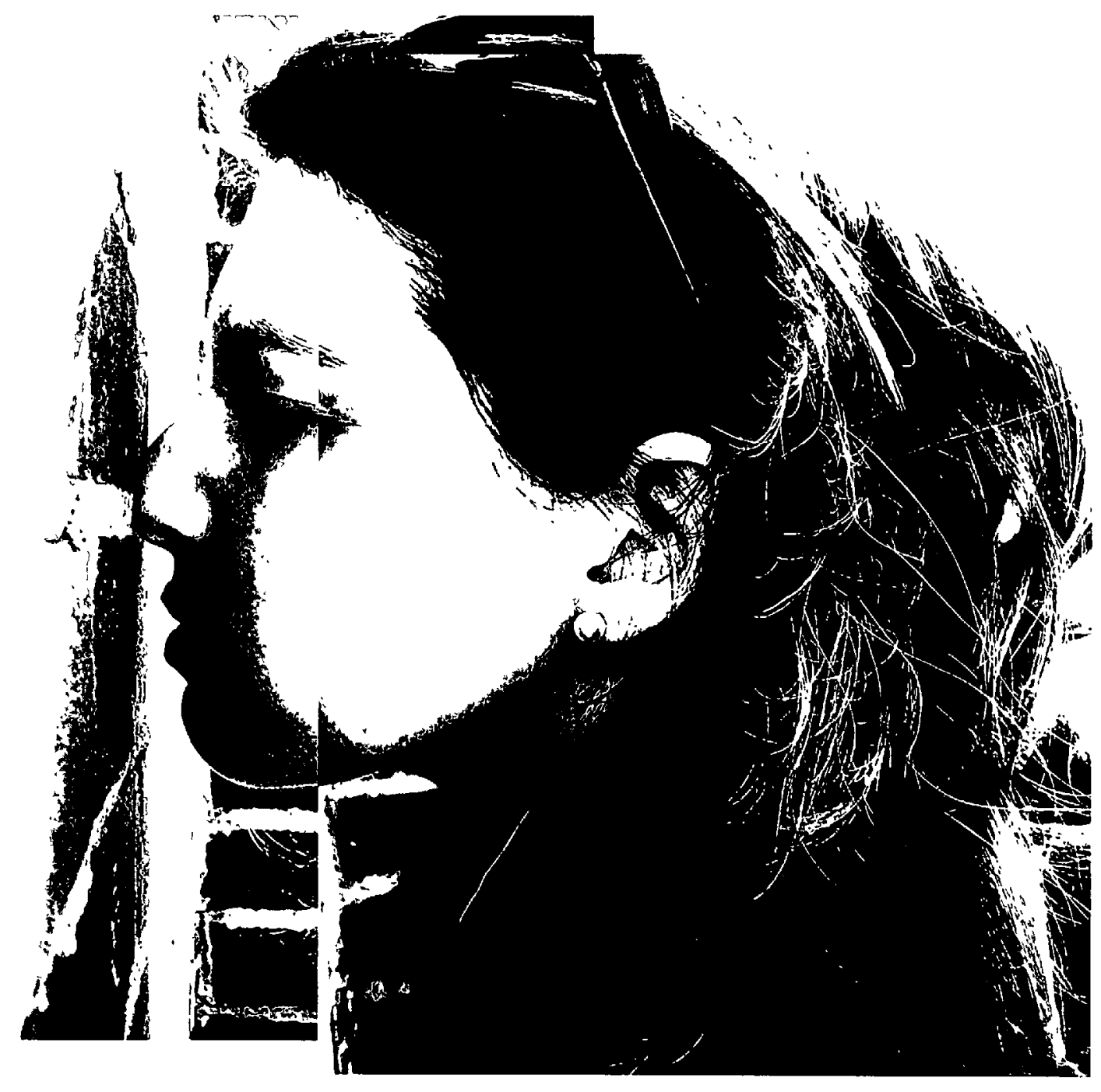




\section{Abstract}

Building design has become heavily dictated by the sense of sight, lacking multisensory qualities and approach. Of all the senses, smell has become the least exercised in the practice of architecture. This thesis ponders the mysterious sense of smell-which conjures long lost memories, creates thresholds to past times and places, affects behaviour and physiology, and makes up a significant component of how we experience space and place (whether we are conscious of it or not)-and seeks to awaken the sense through the design and specification of an office for architects. Exploring the inherent 'odorific' qualities of material and the challenge of representing the invisible, This Project Stinks attempts to extract the latent potential of architectural representation with the combined means of drawing and text to reintegrate smell into the design and experience of architecture. 


\section{Acknowledgements}

The making of this thesis has been a truly rewarding experience but I could not have done it without the encouragement and support of many people. I would like to express my deepest thanks to everyone who helped to make this thesis what it is.

Thank you to Sheryl Boyle, my advisor, for your encouragement and guidance, and also for your confidence in me.

To my sister Amy, for your inspiration and editing prowess, Thank you.

Most especially I would like to thank my family for their love and support in this endeavour. And Rick for his motivation and helping me to stay focused.

And finally, to my colleagues and friends who made this journey worth all the while. Thank you! 


\section{Contents}

Abstract

Acknowledgements

Preface

Introduction

1 Smell: The Forgotten Sense

The Deodorization of Architecture 4

\begin{tabular}{ll} 
Scenting Spaces & 7 \\
\hline Scents in Practice & 8
\end{tabular}

Scents in Practice $\quad 8$

2 Invisible and Indescribable $\quad 13$

$\begin{array}{ll}\text { The Language of Scent } & 13\end{array}$

Representing the Invisible in Architecture $\quad 15$

3 Smells of Place and Time 19

$\begin{array}{lr}\text { Smell and Memory } & 19\end{array}$

$\begin{array}{ll}\text { Nana's House } & 20\end{array}$

"Smellscape" $\quad 21$

The Inspiring Brother of Breath $\quad 23$

Smell and Intuition $\quad 24$

A Product of Our Environment 26

4 This Project Stinks $\quad 28$

Introduction to the Project of Architecture 28

Adaptive Reuse of the Kemptville Armoury $\quad 29$

$\begin{array}{ll}25 \text { Reuben } & 31\end{array}$

$\begin{array}{ll}\text { The Specification } & 33\end{array}$

An Architectural Mise en Abîme $\quad 33$

5 Project of Architecture $\quad 35$

Specification for 25 Reuben Crescent, Kemptville ON 35

$\begin{array}{ll}\text { Conclusion } & 70\end{array}$

$\begin{array}{ll}\text { Coming to Our Senses } & 70\end{array}$

$\begin{array}{ll}\text { List of Figures } & 72\end{array}$

List of Drawings

$\begin{array}{ll}\text { References } & 75\end{array}$ 


\section{Preface}

The persuasive power of an odor cannot be fended off, it enters into us like breath into our lungs, it fills us up, imbues us totally.'

Patrick Süskind, Perfume

Breathing is essential to existence. When we inhale, we smell. As the excerpt above states, there is no way to avoid it. This makes the sense of smell the most fundamental, essential sense. The proximity of the olfactory receptors to the parts of the brain associated with memory, emotion and motivation means that smells affect mood, behaviour, sex and health, among other things. While a smell itself might be fleeting, the impression that it has left on the memory part of the brain is permanent. Smells have the ability to magically project us into a time and place of our past, and conjure memories so embedded in our subconscious that we may not have been able to recall otherwise. In doing so, smells can comfort or irritate, assure or warn, simply by triggering our instincts. Whether pleasant or offensive, odors elicit immediate emotional or physiological responses. But of the 10,000plus smells that humans are able to recognize, only a small fraction can actually be identified by name. In combination with odor's inherent invisibility, this difficulty in expressing the characteristics of or feelings generated by odors, adds to the mystery and allure of the world of scent. $^{2}$

This thesis looks at how we can put to paper a sensation, an indescribable feeling, and reintroduce scent as a prevailing factor in the design of a building.

1 Patrick Süskind, Perfume: The Story of a Murderer (New York: Vintage Books, 1986) 82.

2 Until only recently there was actually very little information known about the science of smelling. In 2004, Richard Axel and Linda Buck won the Nobel Prize for their research into odor perception. 


\section{Introduction}

In 1949, architect Richard Neutra wrote of the importance of the senses that architects generally place secondary to visual perception. "We must guard against the notion that the only sense perceptions which really count are those which are easily and consciously perceived. [...] We should therefore pay full attention [...] to all the non-visual aspects of architectural environmental design." 1 He stressed the interconnectedness of all of the faculties of perception involved in the experience of one's surroundings, especially that of sound and smell, highlighting the perceived inferiority of the sense of smell in building design as compared to the senses of sight and touch.

Smells provide an additional layer to the architectural experience, and can sometimes be more powerful than visual perception. ${ }^{2}$ Odor contributes to the atmosphere and feeling of place, whether noted at the time or not. Often the recall of certain experiences or places is triggered by a distinct smell, meaning that odor perception is situational, contextual ${ }^{3}$, and idiosyncratic, invariably unique to every individual.

However significant odors are to the recalled space, rarely is odor and olfaction consciously integrated into the design process. This is to say that architects do not knowingly use their sense of smell to design and, in the same breath, smell is not generally considered a design element. Vision is not only the dominant sense in perception but also in conception and design. This is evident when looking at the traditional medium of representation (drawing) and the way architects think through a design (sketches). As has already been witnessed in contemporary architecture there is now more attention paid to eliminating odor in architecture than incorporating it. This is part and parcel to the push to create healthy indoor environments that strive to create a safe haven from poor quality exterior

1 Richard Neutra, "The Sound and Smell of Architecture," in Progressive Architecture, November 1949: 65.

2 Realtors, for example, claim that the smell of fresh baking during an open house will contribute to the attractiveness of the home, arguably altering the perception of space.

3 Trygg Engen, Odor Sensation and Memory (New York: Praeger, 1991) 86. 
air. This typically involves the specification of no-odor and low-VOC products to maintain an adequate Indoor Environmental Quality (IEQ). The application of smell in architecture is then relegated to fragrancing spaces with artificial products such as air fresheners and cleaning solutions. Additionally, the immediate, intimate nature of odor perception that elicits emotional and physiological responses is sometimes exploited to influence behaviour and productivity.

The invisible nature of smells may have contributed to the decline of smell in architecture because of the reliance on visual media to communicate ideas-how can we draw the invisible? Moreover, the increasing disconnect between the drawings, which neglect non-visual qualities, and the mundane language of the specification (the textual accompaniment to drawings) may have further contributed to this nonsense. ${ }^{4}$ If the current practice continues, architects will face a further forgetting of the invisible, scentsual qualities of architecture and design. Furthermore, as visual representation will continue to be the primary form of architectural representation, the connection between drawing and language must be more immediate in order to represent smell. We must use language to fill in the gaps that drawing cannot address, or else we face a severe condition of architectural anosmia and lose a sense of smell in architecture.

This thesis explores the instinctual, invisible and ineffable nature of odor and the sense of smell, and the way that smell can be reintegrated into architectural practice. As Helen Keller wrote, "The sense of smell becomes almost a new faculty to penetrate the tangle of things." 5 Smell can be used as a conceptual tool and design element that focuses on the qualitative aspects of architecture, in turn increasing awareness of the sense that is one of the least exercised in architecture.

The Project of Architecture at the conclusion of this thesis seeks to apply these principles through the design and specification of an office for architects.

4 A little wordplay here: nonsense $=$ nonscents, the non-scenting of architecture.

5 Helen Keller, The World I Live In (London: The Century Co., 1904, 1908) 42. 


\section{Smell: The Forgotten Sense}

Helen Keller referred to the sense of smell as the "Fallen Angel", a powerful faculty for perception that is inherent in our being but is often underestimated in its abilities and is secondary to the other four senses of sight, sound, touch and taste. To breathe is to smell; from our first breath, before we opened our eyes, our first contact with the world was through the skin, ears and nose. Deaf, blind, and mute, Helen Keller relied on her three remaining senses to learn about her surroundings. Her nose could warn of a coming storm, or identify who had entered a room. She wrote that without the sensations and information provided by taste, smell, and touch, her world would be nameless and empty.

Anosmia, the name of the condition that literally means "without smell," affects more than simply the ability to detect odors. People who lose their sense of smell often experience a loss of the "heady succulence of life," as Diane Ackerman writes. Some anosmics find the world without smell dull and depressing. A patient of neurologist Oliver Sacks recounted his experience with the sudden loss of the sense: "'[...] when I lost it-it was like being struck blind. Life lost a good deal of its savour-one doesn't realize how much 'savour' is smell. [...] My whole world was suddenly radically poorer...'"1 In the event of the loss of the sense of smell, the sense of taste is the most noticeably affected because of the close relationship of the gustatory and olfactory senses. However, without the subtler ability to smell familiar and comforting odors of a loved-one, anosmia will affect someone emotionally and mentally ${ }^{2}$.

Although the sense of smell is the most primary of the senses, it is considered to be secondary to all other senses, especially the sense of sight. David Michael Levin wrote in his introduction to Modernity and the Hegemony of Vision, "For those of us who can see,

1 Oliver Sacks, The Man Who Mistook His Wife for a Hat (New York: HarperPerennial, 1990) 159.

2 Diane Ackerman, A Natural History of the Senses (New York: Random House, 1990) 41. 
visıon is, of all the modes of perception, the one which is primary and predominant, at least in the conduct of our everyday lives." ${ }^{3}$ Though daily experience still commands the use of touch, taste, smell and hearing, the dominance of vision has led to the attrition of the other senses. Even the term 'aesthetic' has come to mean pleasing in appearance, when its original meaning actually referred to perceiving with all the senses. ${ }^{4}$

This is not to say that we have all stopped using our sense of smell completely, but the reliance on eyesight and the diminished use of our noses in conscious perception has developed a reduced sensitivity to smells. Because the intuitive nature and the subliminal operation of the sense of smell it will always be a factor in the subconscious perception of space and place.

\section{The Deodorization of Architecture}

Odor was once a significant component in architecture. Fragrances used in religious monuments and traditıons allude to spirits, heaven or the otherworldly. ${ }^{5}$ For such uses, however, sacred spaces were not simply perfumed; scent was incorporated directly into the materiality of the building. For example, essences such as rose water, musk, or myrrh were mixed into the construction mortar of Middle Eastern mosques. ${ }^{6}$ The heat of the sun released

3 David Michael Levın, ed Modernity and the Hegemony of Visıon (Los Angeles: University of Calıfornıa Press, 1993) 2

4 "Aesthet $I C$ ", from the German asthetısch, derıved from the Greek aisthetikos meanıng "perception by the senses," from aisthanesthai "to perceive or feel "In Germany in the mid-1 $8^{\text {ih }}$ Century the term came to refer to beauty or taste (as in style, not the gustatory sense) and has contınued with this definition since History of the term summarızed from. Julia Cresswell, "aesthetıc," Oxford Dictionary of Word Origins, Oxford University Press, <http //www oxfordreference com/views/ENTRY html'subview=Main\&entry=t292 e103>; Constance Classen, Worlds of Sense (New York Routledge, 1993) 60.

5 Further reading on the topıc of odor in relıgıous practıce in collection of essays in "Part VII: Sublıme Essences" of The Smell Culture Reader, ed Jim Drobnick (New York Berg, 2006) 371-430

6 Anna Barbara and Anthony Perliss, Invisible Architecture Experiencing Places through the Sense of Smell (Milan Skıra Editore, 2006) 110 
the aromas from the walls, permitting scent to play a role in the experience of the place both inside and out. Elsewhere, certain architectural features or even entire palaces were constructed of naturally aromatic woods like cedar or sandalwood. ${ }^{7}$ Although this choice of material was due to the wood's natural resistance to rot and pests, when finished without lacquers, the smell of the wood would occupy the space. It is said that the 2000-year-old sandalwood door to the temple of Somnath still impresses the

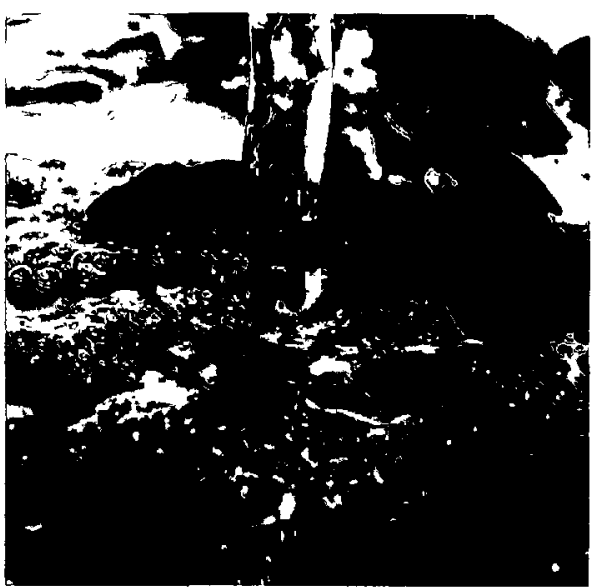

Figure 1. Rosewater

Source: chttp://www ehow.co.uk/how_2323532_make-triple-rosewater. html> (Accessed 7 October 2009) woody-spicy scent upon those who enter.

The deodorization of architecture may well have begun in Europe in the $18^{\text {th }}$ century, when the spread of disease was associated with foul odor. Rodolphe el-Khoury explains that the paving of streets in France was one example of the deodorizing attempts to keep malodorous vapours from escaping the earth. ${ }^{8}$ Plastering and the white-washing of walls was believed to neutralize the miasmic effects of unpleasant and harmful odors that emanated from walls. $^{9}$

Prior to these first architectural deodorization attempts, people fragranced themselves as well as spaces, as it was believed that 'good' smells protected against harmful 'bad' odors. The sachet, a silk pouch

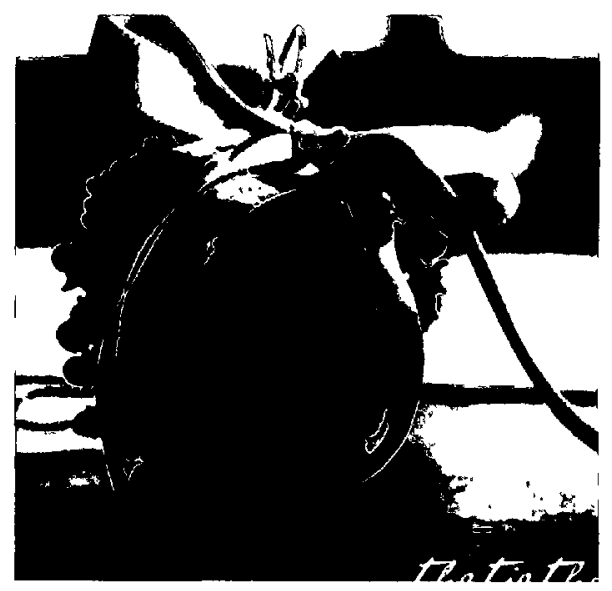

Figure 2. A modern pomander

Source: The Tie That Binds Us ehtip:/thetiethatbindsus com/wpcontent/uploads/2010/03/pomanderfinished.jpg> (Accessed 29 July 2010 )

7 Ackerman 60; Barbara and Perliss 65.

8 Rodolphe el-Khoury, "Polish and Deodorize: Paving the City in Late Eighteenth-Century France," in The Smell Culture Reader, ed. Jim Drobnick, 18-28 (New York: Berg, 2006) 22.

9 Ironically, the foul, sulfuric smell of the wet plaster was not itself healthy. It only became safe after it had dried and stabilized. 
that held fragrant spices, and the pomander, an apple dressed in cinnamon and cloves, were two fragrant devices that were widely used as a personal defense of the plague. Similarly, the white linen collars, sleeves, undergarments and lace detailing in the clothing of the $18^{\text {th }}$ and $19^{\text {th }}$ centuries were visible evidence of personal cleanliness, purity, and hygiene. ${ }^{10}$

Over time, the white wall has come to represent cleanliness and sterility, likely "by virtue of its capacity to translate the olfactory condition of odorlessness into an image."11 White walls and highly polished surfaces became characteristic of the Modern movement. Images of Mies van der Rohe's Barcelona Pavilion or Le Corbusier's Villa Savoye, for instance, certainly project an idea of hygiene and clean taste and most definitely do not suggest odor of any kind.

Ahead of his time, architect Richard Neutra speculated the direction that modern architecture was headed:

It remains questionable whether future designers will, by mere negation, content themselves simply to produce abstract odorlessness (if this can be done at all). Perhaps they will learn to know the pertinent physiological effects of the exhalations of their structural and finishing materials. ${ }^{12}$

In effect, he predicted that even the clean-looking surfaces and finishes of the Modernists would later (ironically) contaminate the interior environment.

10 El-Khoury 20.

11 El-Khoury 27.

12 Neutra 66. 


\section{Scenting Spaces}

The tendency toward 'odorlessness' in buildıngs has truly affected the quality of interiors So much so that the inverse has actually occurred Resultıng from the need for incessant apparent cleanlıness, spaces are artificially scented to add to the overall perception of 'clean' An entıre thesis (not this one, however) could be written on the perceptual ımpact of aır-fresheners, odor-neutralızers, and scented cleanıng products withın a space

Another practice that is in common use today takes advantage of the emotional and physıological effects of odor on individuals Environmental fragrancıng, of varyıng forms, is exercised all over the world as a result this premise For example, smell is used as a marketıng tool to lure customers into a restaurant or boutıque, keep shoppers shoppıng, and keep office workers productıve The wood-burnıng stoves at Forno Antıco Pizzerıa or Kettleman's bakery in Ottawa exhale the aromas of the ovens and the food cookıng inside them out into the air to be caught by the noses of passersby In office buildıngs, shopping malls and aırports, odor is pumped into the forced-air systems subtly "Odors do not become consciously perceptıble untıl quite strong, but they are always subconsciously effectiveand just as effective even when undetectable by the nose "13 Peter and Kate Damıan list the objectıves of environmental fragrancıng to ıncrease or enhance aesthetıcs, to optımıze performance and creativity at large, and to improve aır quality. ${ }^{14}$

Although the practıce of force-fragrancing may work effectively to achieve a certaın (economic) outcome, the addition of scents is only considered as an afterthought to the design process It does not demonstrate how architects can incorporate Smell ${ }^{15}$ into the makıng and the creatıng of space, which is the intent of this thesis

13 Peter Damıan and Kate Damıan, "Envıronmental Fragrancıng,' in The Smell Culture Reader, ed Jim Drobnıck (New York Berg, 2006) 151

14 Damıan and Damıan 150

15 The dictionary lists the word "smell" as both noun and verb As a verb, "smell" means to either detect or emit an odor (depending on its usage) As a noun, smell refers to an odor or scent The usage of "Smell" in this thesis is a combined meaning that encompasses the action, the odor, and the sense of smell 


\section{Scents in Practice}

The following projects are examples of artists and architects that have incorporated Smell into their practice. The purpose of Smell varies with each project and architect, though most use odor to enhance the experience of a place. Although there are many other applications of Smell to architecture, the following projects demonstrate a few ideas that include bodily perception and behavioural response to scented spaces, using odor as a device for navigation and way-finding, as well as issues of historic conservation, regionalism and memory.

Artist, odor researcher and chemist Sissel Tolaas stresses the importance of using the nose to bring a greater awareness of our surroundings. She calls herself a "Professional Provocateur"; the New York Times calls her the most controversial figure in the fragrance industry. ${ }^{16}$ Her interest lies not in the manufacture of perfumes but in everyday odors; and her research focuses on increasing tolerance for foul odors and using smell as a communication tool. She asserts that the nose is a powerful tool, considering that everyone has one and it is completely free to use. She works primarily with children, because they are curious, unbiased, and have a heightened awareness of their surroundings. Children's noses are easier to train to detect and tolerate different smells, especially those which most people would find offensive. Her artwork provides an outlet to test her research. A range of projects strive to create an awareness of a powerful yet forgotten sense, and challenge the sense of sight as the dominant sensory receptor of experience. Her projects include an installation of a wall that releases human body odor, an analysis of the odors contained in articles of clothing, and the analysis of the smells of all the neighbourhoods of a major city.

Architect Philippe Rahm incorporates smell into his exhibition installations because of the physiological and behavioural effects of certain odors. Scented paint for the Peinture

16 Susie Rushton, "The Sweat Hog," The New York Times, Newspaper (nytimes.com, August 27, 2006). 
Placebo project ${ }^{17}$ acted as an instigator for the program or usage of the room. The interior of two rooms were both painted white but with different scents mixed in: one with ginger, which arouses, and the other with orange-blossom, which calms. The project itself was more of an experiment in physiology and interior bodily perception, but what is significant to this thesis is that odor was used to subliminally suggest the purpose of the space. Although such a minute quantity of odor added to the paint is not detectable to the human nose, the physiological response to the odor is notable. Many of Rahm's recent works deal with air temperature and movement through convective currents in interior environments. One element of

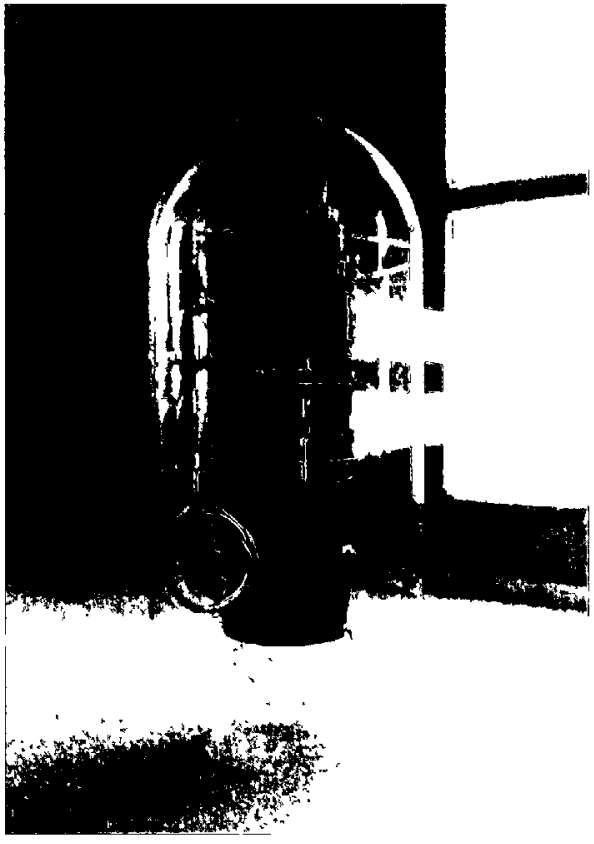

Figure 3. Double-flow air-exchanger for "Deterritorialized Milieus."

Source: www.philipperahm.com <http://www,phılipperahm. com/data/projects/deterritorializedmilieus/index.html> 2009. (Accessed 29 July 2010) "Deterritorialized Milieus" (2009) is a double-flow air exchanger that contains wood samples from forests near Paris. The air returning to the interior space contains a very subtle trace of the earthy woods. Again, although Smell was not the predominant idea in this project, as his focus remains on creating miniclimates and circulating air, the material choice plays a role in the experience and perception of the interior environments that Rahm creates.

In the early 1970s Charles Moore and Richard B. Oliver designed a house for a blind man and his family. Their strategy was to permit the homeowner

17 With Jean-Gilles Decosterd, Dr. Patrick Lemoine, and AIR. Exhibited at Musée d'art moderne de la ville de Paris, October 2001 - January 2002. 
to orient himself based on his sense of smell, sound, touch, and the perception of light. Orange and lemon trees in the Orangerie and Conservatory, in which the central circulation elements are also located create an olfactory landmark and pleasant experience for both the blind and sighted members of the family. The natural ventilation system also helps to carry odors through the home, and provides a way to indicate the orientation of the home with respect to its site context. Depending on the direction of the winds, the smell of pine from the forest or peaches from a nearby orchard filters through the house.

Two projects by West 8 enhance the experience of place through the use of smell. Pine Cone Garden of 2003 is simply that: a walled garden filled with pinecones with a strong smell that recalls a nearby pine forest. City on Fire/City in Bloom (2007), an installation located in Schouwburgplein, a main square in Rotterdam, remembered the city's bombing through the transformation of fire into flowers. A sculpture of red and purple flowers-over 64,000 of them-symbolize the flames and demarked the extent of the destruction while also representing the "blossoming" of the city after the war. ${ }^{18}$

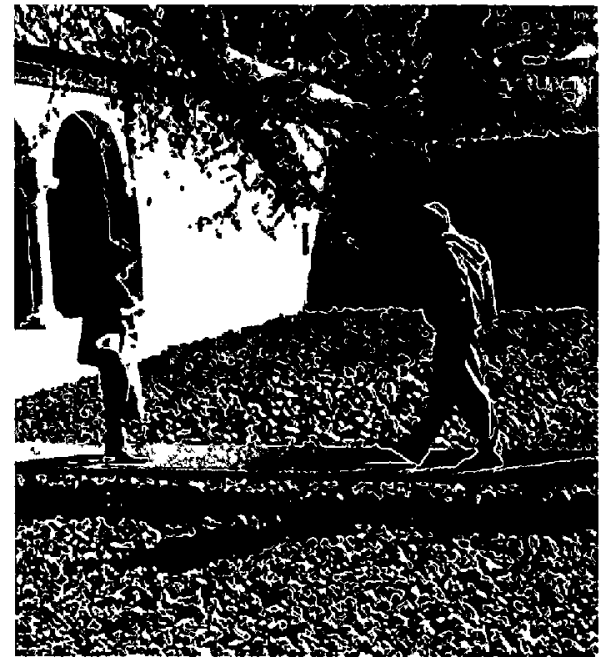

Figure 4. Pine Cone Garden by West 8.

Source West 8, "Pine Cone Carden" < http / Nwwww westB nl/ projects/gardens/pine_cone_garden/s 2003 (Accessed 29 luly 2010)

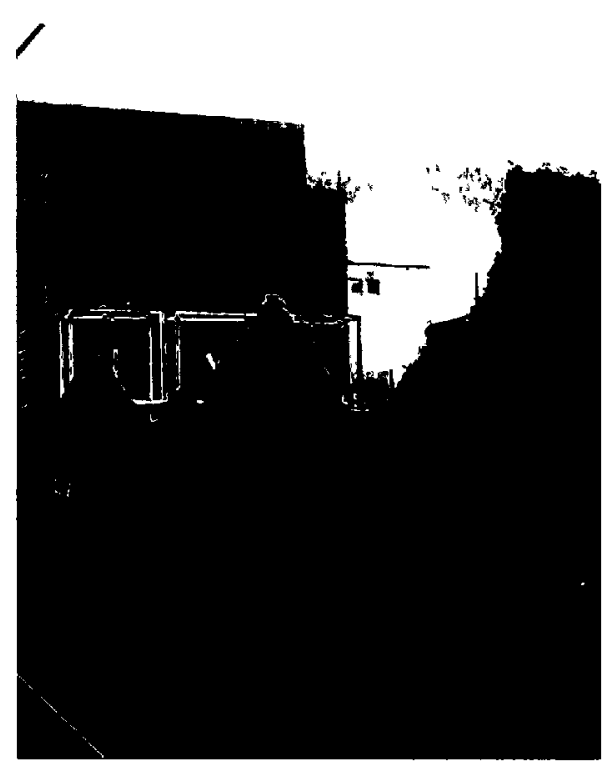

Figure 5 City on Fire/City in Bloom in Rotterdam, by West 8 .

Source Michiel van Raaly, "Fire Border Rotterdam" < hitp // www elkongraphia com/p=1688> 2007 (Accessed 29 July 2010)

18 Unfortunately, not having visited the installation, I cannot describe how the smell of thousands of flowers of City on Fire/City in Bloom would have affected the city square My Imagination will have to fill in the blanks. 
The tomb-like Irish Pavilion (titled $\mathrm{N}^{3}$ ) for the 2000 Venice Architecture Biennale designed by Tom dePaor Architects was built from 21 tonnes of turf briquettes from Ireland's own soil. The tiny structure forced the visitor to get intimate with the 3000 -year-old material that was described as smelling "burnt, [and] sickly sweet" by historian and author Shane $\mathrm{O}^{\prime}$ Toole. The choice of material provides a social and historical commentary in addition to an extensive story behind the design of the pavilion. At the conclusion of the Biennale the pavilion was returned to its original form of soil and relocated to a public garden in Venice.

This last example discusses the conservation of the smell of architecture. In an article featured in AA Files No. 57, Jorge Otero-Pailos makes a criticism of architectural preservation practices that are geared towards the visual. Focusing on Philip Johnson's Glass House (1949) he argues that there are no public records that describe the smells that would have been experienced during its time and when preservation works began there was no attempt to preserve its odors. ${ }^{19}$ So, in collaboration with a perfumer he

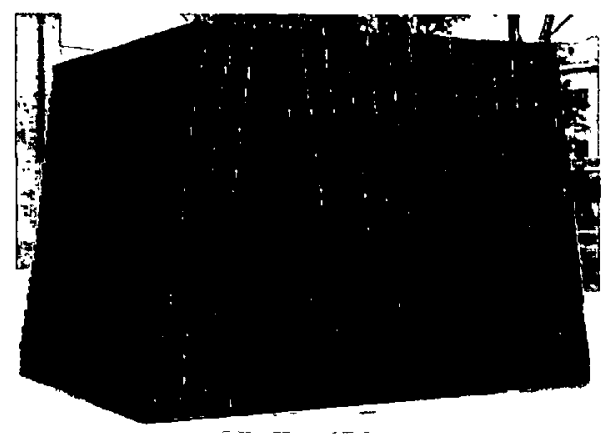

Figure 6. Irish Pavilion " $\mathrm{N}^{3}$ " by Tom dePaor Architects.

Source: Dennis Mortell, "N3, Spazio Thelis, Arsenale di Venezia," < http://ireland.archiseek.com/lesserae/000006.html> 2000. (Accessed 22 April 2010)

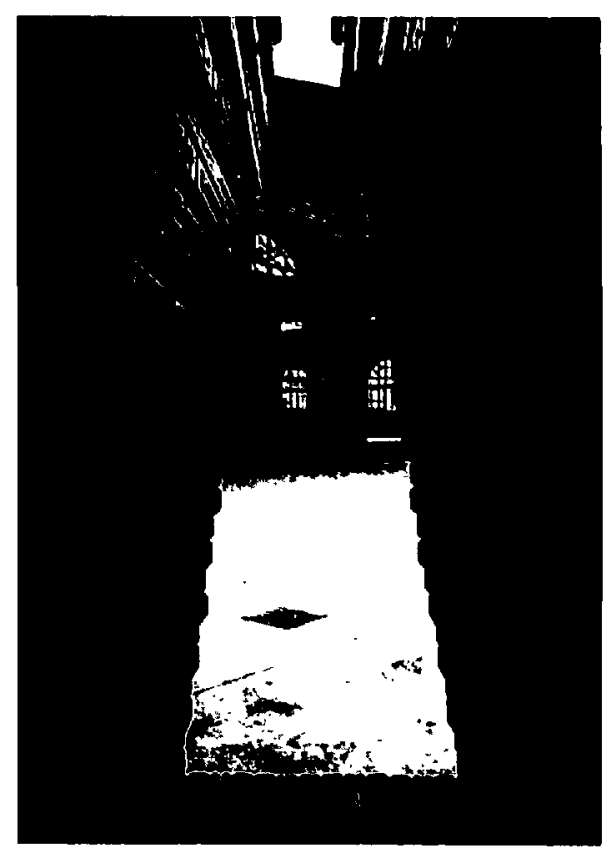

Figure 7. View from inside " $\mathrm{N}^{3}$ " by Tom dePaor Architects.

Source: Dennis Mortell, "View out from within $\mathrm{N}^{3}, "<$ http:// ireland.archiseek.com/tesserae/000006.html> 2000. (Accessed 22 April 2010)

19 Otero-Pailos also adds that in addition to the lingering odors, the Glass House actually contained visible traces of the impact of odor in the building. White surfaces became yellowed with years of cigarette and cigar smoke; humidity caused leather tiles to peel from the washroom ceiling.

However, during restoration, all of these traces were removed. Otero-Pailos argues that the removal of such indicators and the deodorization of the Glass House not only return it to its 'preuse' state but also impose contemporary ideals upon it. That is, with the deodorants, fragrance-free labels, and unscentedness in today's society, for example, visitors to the Glass House expect this same level of 'clean'. In effect, the preservationist 
recreated some of the odors that he believed would have been present in the Glass House: The Glass House in 1949 (a combination of newly lacquered wood, stainless steel, and fresh plaster), The Glass House filled with cigarette smoke, and the smell of 1950's men (a mixture of Old Spice, Canoe, Acqua Velva). In true scratch-and-sniff form, the reader can activate each olfactory reconstruction by rubbing the scent-patch on the page to smell the Glass House as it would have been from 1949-1969. Otero-Pailos' endeavor is truly the first odorpreservation attempt that I have encountered in the process of this thesis.

has distorted the representation so that it is compatible with the deodorized, fragrance-free and unscented contemporary visitor. 


\section{Invisible and Indescribable}

\section{The Language of Scent}

Although there is a range of thousands of smells detectable to the human nose, there is an awkward inability to describe smells accurately. In her book $A$ Natural History of the Senses, Diane Ackerman contemplates the indefinable nature of odors, "Smells coat us, swirl around us, enter our bodies, emanate from us. We live in a constant wash of them. Still, when we try to describe a smell, words fail us like the fabrications they are." (Renowned odor-perception specialist and professor) Trygg Engen referred to this issue as the "tip-of-thenose state. ${ }^{\prime 2}$ Despite the lack of a specific vocabulary to actually describe scents, there are means of expressing the smell of an odor with words. Using comparison, an odor smells like something else. For example, sulfur smells like rotten eggs, or the carpet smells like wet dog, but how do rotten eggs and wet dogs smell? It is common to reach for familiar describing words pertaining to the other senses for terms that are also suitable to describe smells. As such, certain smells can be described as being 'sharp,' 'sweet' or 'green.' ${ }^{3}$ Descriptors for taste are most commonly used because of the close relationship of the gustatory and olfactory senses. For instance, sugar has no smell, but we can say that something sugary smells sweet

\footnotetext{
1 Ackerman 7.

2 Engen 85.

3 In a 2005 lecture for Ted.com, biophysicist Luca Turin explained to his audience that a 'green' note is a perfumery term for scents that smell of things that are green. For example, the colourless Cis-3-Hexanol, which smells of cut grass, is 'green'.
} 
because we associate the taste of sugar with the smell that is exhaled across the olfactory receptors. But even then, this attempt does not quite express the nature of the smell.

With experience, one can speak of smells through rather technical terms to describe an odor's temperature, direction, pressure, spatial distribution and class. Though many have tried to categorize odors succinctly, there are many classes in which certain smells can be organized. These classes might include fragrant/floral, resinous/camphoric, acrid/ pungent, musky, minty, foul/putrid, ethereal, fruity; however, there is currently no universally accepted list of categories. ${ }^{4}$

Perhaps because no one could agree on which system categorizes scents the best, perfumers, sommeliers and other fragrance corporations have developed their own particular languages to talk about smells. ${ }^{5}$ In these industries, where odors are created or composed, many of the terms are borrowed from music, and the auditory sense. Notes, accords (similar to musical chords), compositions and harmonies, speak of the arrangements and layering of different scents but not of the smells themselves.

4 For a comprehensive list of the various systems used to categorize scents refer to Invisible Architecture by Anna Barbara and Anthony Perliss, pages 115-117.

5 The creation of company-specific vocabularies is likely also a result of the extreme secrecy within the fragrance industry.

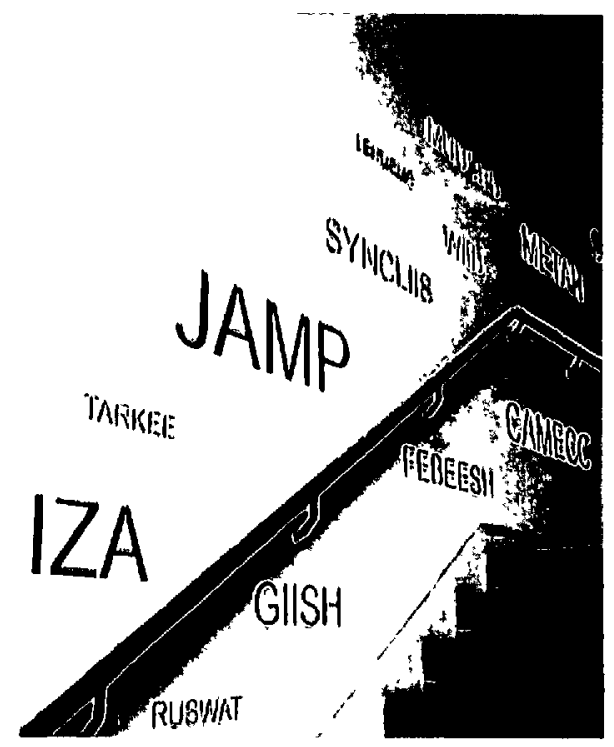

Figure 8. Sissel Tolaas and re_searchLab's "NASALO" dictionary as wall art, featured at the Liverpool Biennale in 2006.

Source: "mac-lastic," "Sissel Tolaas @ FACT, Liverpool Biennial," < hitp://www flickr com/pholosimac-tastıc/308802805/> 14 November 2006. (Accessed 29 July 2010) 
Often smells are simply described as "good" or bad," but this does not indicate anything towards the nature or composition of the odor. Interestingly, the words for "good" smells, including perfume, aroma and fragrance, are outweighed by the words for "bad" smells. Most of the terms used to describe odors typically have a negative connotation: an odor stinks, reeks, or is foul, rank, putrid, or the like. To say that something "stinks" in presentday terms, generally translates to mean that the thing is awful, and makes no reference to the odor. ${ }^{6}$ Even the word smell itself can be construed negatively even when asking, "What's that smell?" or stating "You smell." This likely correlates with the perception that odor is taboo and consequently there is a desire to eliminate it from our everyday environments.

This inability to talk about the nature of smells as well as specific characteristics of an odor certainly poses a problem. Like a muscle that needs to be worked to remain strong, the sense of smell must also be exercised. If we cannot formulate the words to describe a smell and its invisible nature means that it cannot be represented visually, when applied within the context of architectural practice it is likely to be forgotten.

\section{Representing the Invisible in Architecture}

Traditionally, drawing is the architect's primary medium, but how does the architect represent the invisible qualities of a space? In the dream-like process of inventing architectural spaces architects may imagine feelings, sounds, smells, light quality, temperature, and maybe even tastes of spaces, but these elements are left out when the idea proceeds to paper. ${ }^{7}$

6 The title of this thesis This Project Stinks challenges the language of odors: Does the project really smell bad? or does it just possess odor?

7 Adrian Forty, "Language and Drawing," in Words and Buildings: A Vocabulary of Modern Architecture

(Thames \& Hudson, 2004) 31. 
Therefore, drawing alone cannot represent the invisible qualities of architecture. What, then, will happen to the things that cannot always be represented explicitly through visual means, like mood, atmosphere, and smell? Odor requires another medium of expression altogether, because unlike mood and atmosphere, smell is difficult to imply visually.

Fragrance chemist, Luca Turin wrote that after an experience that he had with a particular smell a realization came to him about it in the form of "a picture, not words":

I remember once walking across a parking lot between industrial buildings at the headquarters of a perfumery firm and suddenly catching an intense whiff of some molecule they had just finished making and were probably dispensing into drums. It smelled of fruit, but not of any particular fruit, perhaps some compromise between peach and apricot, though more vivid and less subtle than either. It only lasted a few seconds, but left an impression of indefinable oddness. It was only much later that I managed to put a finger on why it was odd, and it came to me suddenly as a picture, not words [emphasis added]. What was strange about the fruity whiff was what was missing: colour. The grey of the concrete, the pleasant wind in the blue sky, the green of the English countryside - all were accounted for, pictures and smells present and correct. Suddenly this huge orange-coloured smell comes out of nowhere. To justify its presence, there should have been a pile of ripe fruit one hundred metres high, but there was nothing, only a light breeze coming from a nondescript building... ${ }^{8}$

Turin's experience offers an alternate method to help communicate the feelings given by the scents of things. If something cannot be explained with words, it might be better expressed with an image. Similarly, Engen wrote that even though we cannot recall the exact smell of an odor, in the attempt to, we end up visualizing the object from which the smell originated to help convince ourselves of the smell: "Most people believe that they can indeed recall odors, but they will usually agree after further introspection that what comes to mind is some object associated with an odor, such as the visual image of a lemon rather than a lemony odor." ${ }^{\prime 9}$ Furthermore, bringing attention to the sense of smell does not demand the elimination of the sense of sight. Instead, the visual can be used advantageously help project

8 Luca Turin, The Secret of Scent (London: Faber and Faber Limited, 2006) 8-9.

9 Engen 6. 
the intended message. This could be through use of image, the implication of texture, or with colour, as Turin discovered.

The last line of the Shel Silverstein (Figure 9) poem poses the question: "Will you draw an invisible picture for me?" Silverstein's poetry is usually accompanied by his own illustrations. For "Invisible Boy" the rectangle he traces above the text depicts the edges of the invisible picture. In this way, his use of image ironically enhances the text, adding another layer of understanding.

Similarly, in architecture, when drawing proves insufficient to describe a spatial intention the architect will explain in words. The same works conversely, whereby drawing can supplement text. Either verbal or textual, language continually accompanies the traditional visual representation of the architect's idea. Language, like drawing, occurs at every stage of the design process, beginning with the first meeting between architect and client. Adrian Forty states, "it would be wrong to regard language as merely an after-effect of design: it more generally exists already, but is pulled into design to do something for it that the somnabulist [sic] world of drawing is not able on its own to provide. ${ }^{\prime 10}$ Thus, language is a necessary accompaniment to provide meanings to things that some drawings are unable to convey:

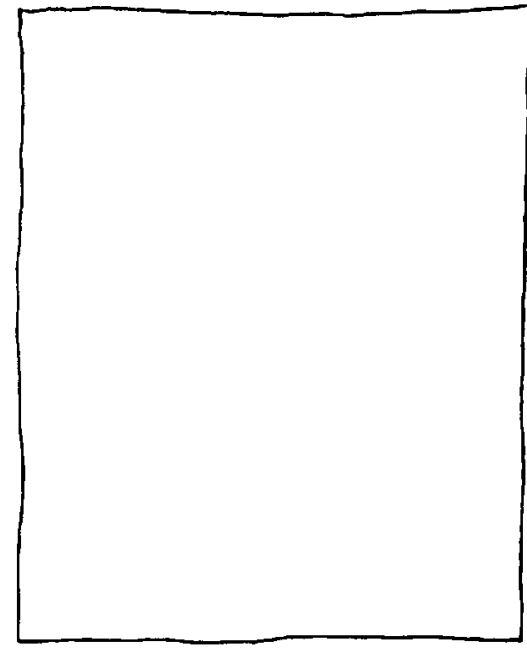

INVISIBLE BOY

And here we see the invisible boy In his lovely invisible house, Feeding a piece of invisible cheese To a little invisible mouse.

Oh, what a beautiful picture to see! Will you draw an invisible picture for me?

Figure 9. "Invisible Boy," a poem and illustration by Shel Silverstein.

Source Shel Silverstein, "Invisible Boy," Where the Sidewalk Ends (New York HarperCollıns, 2006) 
invisible phenomena, such as "nuances, moods and atmosphere"11 as Forty writes. As there are limitations to both language and drawing, architects cannot only rely on one means to express their ideas. Therefore, the simultaneous operation of image and language, either text or speech, will facilitate the correct reception of the architect's intentions.

In current architectural practice, the specification document is the textual counterpart to drawings that "sets out materials, construction methods and standards of work."12 Although it details certain invisible aspects of construction, such as temperature and indoor environmental quality, the specification does not currently fulfill its potential to speak about the intended atmosphere, moods and odors of the building. Any attempt to include certain invisible qualities of a project still proposes quantitative measures and instructions derived from these qualitative aspirations. And though specification and drawings are intended to operate together, in current office practice the two components still function separately. As a consequence, the traditional form of the specification has added more distance between the invisible and visible elements of architecture. The specification is a viable document that has the capacity to do more than just measure materials and methods of construction; it could capture in words the invisible, sensual aspects of the project. As Thomas suggests, it could create poetry of the material definitions that make up a building, ${ }^{13}$ and provide a vehicle to revive the non-visual senses.

11 Forty 38.

12 Katie Lloyd Thomas, "Specifications: writing materials in architecture and philosophy," ARQ, 2004: 280.

13 Lloyd Thomas 283. 


\title{
3 Smells of Place and Time
}

\author{
Smell and Memory
}

The strongest memory of a place is often its odor. [...] A particular smell may make us secretly re-enter a space that has been completely erased from the retinal memory; the nostrils project a forgotten image and we are enticed to enter a vivid daydream.'

Juhani Pallasmaa, An Architecture of the Seven Senses

Helen Keller experienced the world through the senses of touch, taste and smell.

In her book, The World I Live In, she describes the power of Smell to bring long-forgotten memories to life:

A whiff of the universe makes us dream of worlds we have never seen, recalls in a flash entire epochs of our dearest experience. I never smell daisies without living over again the ecstatic mornings that my teacher and I spent wandering in the fields, while I learned new words and the names of things. Smell is a potent wizard that transports us across a thousand miles and all the years we have lived. The odour of fruits wafts me to my Southern home, to my childish frolics in the peach orchard... The faintest whiff from a meadow where the new-mown hay lies in the hot sun displaces the here and

1 Juhani Pallasmaa, "An Architecure of the Seven Senses," in Questions of Perception: Phenomenology in Architecture (Japan: Architecture and Urbanism, 1994) 32. 
the now. I am back again in the old red barn. My little friends and I are playing in the haymow... ${ }^{2}$

Like Keller, many have written on the extraordinary ability of an odor to unearth memories from the subconscious and transport the mind to a place and time of the past. The funny thing is that this seemingly strange phenomenon is actually very common. During the process of this thesis, friends, family members, and even strangers continually shared their personal experiences of remembering familiar places through the simple whiff of an elusive smell. The scent and the memory it triggers are unique to each person, but the experience itself is similar. The following personal anecdote describes a memorable encounter with the unmistakable smell of my great-grandmother's home.

\section{Nana's House}

My grandparents currently live in the house previously owned by my greatgrandmother, Nana. There was a particular smell that Nana's house had, maybe a result of what cleaning products she used or what cooking smells lingered in the carpet and upholstery, but it was distinct nonetheless. After her death, about 13 years ago, Gramma and Poppa began to make her home their own with little renovations here and there. Nana's home now smelled like Cramma's, even though it looked the same for the most part. One day I was passing through the dining room to the living room and the familiar smell of Nana's house caught my senses. It felt like I had momentarily crossed into a time in the past, and I was able to visualize the room exactly the way it was 15 years before-the rough texture of the green carpet; her favorite plush brown sitting chair, only an arm's length from the old beige rotary dial phone (I recall its Brrrring! Brrrring!); the white sofa under the large picture window; the wooden coffee table (that my

2 Keller 65-67. 
sister and I commandeered whenever we needed a make-shift Barbie house); and vaguely I remember the piano that used to be behind where I was standing that I only ever once heard played.

Then as suddenly as it came, it was gone-all that in a mere second. Eager to relive that fleeting moment, I took a step backward with hope to walk through that smell again. But the smell had only lingered there long enough for me to catch it just that once; the moment had passed again into memory.

Thinking back, personal experience revealed a few things about this phenomenon: It was highly unpredictable, and the smell only lasted for a second, maybe even less, but was instantly recognizable. The immediate link to the memory was a distraction from the original purpose for entering the living room. The smell quickly vanished, and as a result it is impossible to remember exactly how it smelled. Moreover, the smell itself cannot be recreated at will, but the sensation that it gave can sometimes be retrieved when trying to recall the odor. Overall, this feeling creates the impression of being in two places, or two different times simultaneously, in effect creating a threshold between two worlds: the real and the imagined.

\section{"Smellscape"}

Smells are unique to places. Odors provide an essential layer of character to place experience permitting that place to be easily recalled or remembered in specific detail. In fact, odor memory supersedes visual and auditory memory, which typically diminish over time. ${ }^{3}$ Imagine for a moment that all memories obtained from sensory experiences

3 Engen 81. 
are photographs filed away in the subconscious: pictures acquired through sight and hearing will fade with time but olfactory postcards will remain sharp and crisp. These recognizable smells of place are influenced by people, their culture and food, as well as geography, climate, landscape, and environment. J. Douglas Porteous, who coined the term "Smellscape," writes that "like visual-impressions, smells may be spatially ordered or placerelated. ${ }^{4}$ This statement implies that in addition to the visible layers of space-perception, odor plays a significant role in the experience of a place. On that note, Richard Neutra also wrote of the "subconscious architectural associations of smell" that endow the memories of childhood places. Although certain odors may not have been consciously noted at the time, "the school room smell" and the aura of "books read between high school library cases" $^{\prime \prime}$ certainly characterize the memory of the architecture, arguably even more so than the physical characteristics of the space. Porteous states, "In combination with vision and tactility, smell and the other apparently 'non-spatial' senses provide considerable enrichment of our sense of space and the character of place." ${ }^{\prime 5}$

The distinctive smell of a birch grove enhances the experience of the Finnish pavilion at Expo2000 in Hanover. Designed by SARC Architects, a pair of long and slender buildings sandwich the birch grove, which contains 70-plus trees and native plant species including bilberry bushes, wild strawberries, and moss from Lapland. Visitors access both sides of the pavilion by crossing one of the several wooden bridges that pass through the mini-forest. A visitor to the Finnish pavilion during the Expo claimed, "it even smelled like Finland!"6 The entire structure, aptly named, "Windnest," is focused inwardly upon

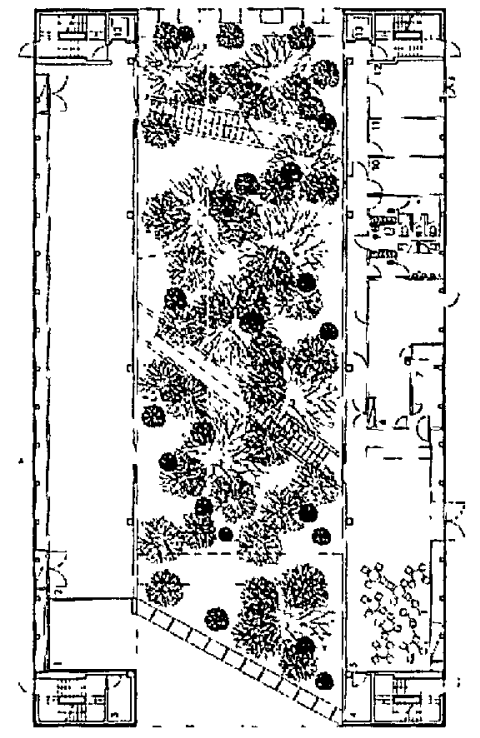

Figure 10. Plan of Finnish Pavilion

Source: SARC Architects Lid., in Marına Flamme-Jasper, Architektur Architecture EXPO 2000 Hannover (Osfilldern: Hatje
Cantz Verlag, 2000) 126.

4 J. Douglas Porteous, "Smellscape," Progress in Physical Geography 9, no. 3 (September 1985): 359.

5 Porteous 360.

6 Sabine "Sabsi", "Finland at Expo 2000" a Finland Travel Page, September 14, 2002, http://members. virtualtourist.com/m/tt/5637/ (accessed April 2010). 
the forest: the exterior façades of the two buildings are clad in heat-treated birch wood, while the courtyard façades are completely glass. This calls further attention to the importance of the birch grove, but also "symbolizes the significant role the forest plays in Finnish society." Images of the pavilion are quite seductive; having not visited Expo2000, one can only imagine how the scent of the grove would have enriched the whole experience.

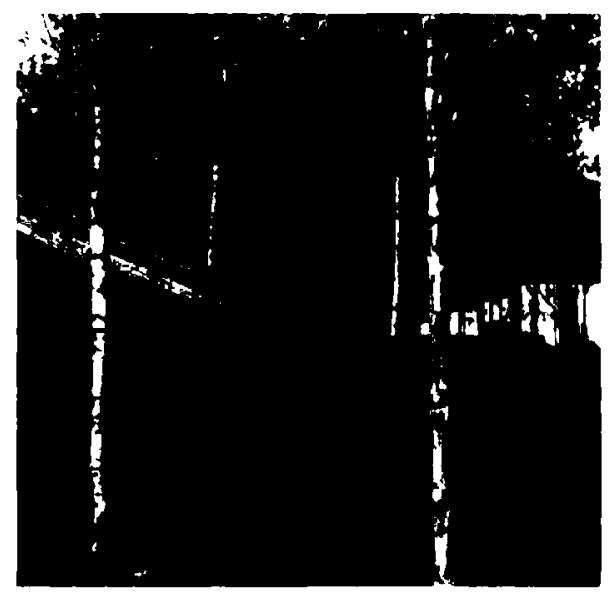

Figure 11. Berch grove of Finnish pavilion

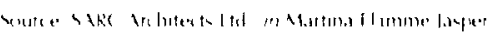

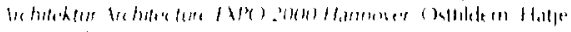

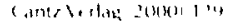

\section{The Inspiring Brother of Breath}

for people could close their ears to melodies or deceiving words. But they could not escape scent. For scent was a brother of breath. Together with breath it entered human beings, who could not defend themselves against it, not if they wanted to live."

Patrick Sushind. Perfume

Olfaction naturally occurs when we breathe. Breathing is essential to life-it does not require conscious thought-it occurs spontaneously. The word "breathe", from the Latin spirare, shares the same origin as the word "inspire": the act of drawing air into the lungs, but also meaning to influence, affect, or motivate. In many languages, the word for "smell"

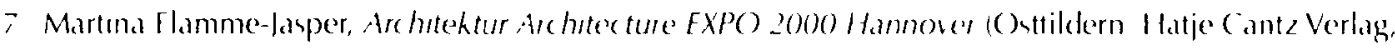
20001126.

8 Sushind 155 .
} 
also has several meanings, translating as to sense, to feel, to perceive, or to hear. In some instances these meanings are synonymous. For example, the French verb sentir means to smell, to taste, to sense, to feel, to perceive; and the Finnish haistaa means to sniff, to smell, and also to suspect, sense or feel. These definitions considered simultaneously produce an effect on the smeller many times more potent than that caused by any single definition: considering all its possibilities, to smell is to feel inspired.

\section{Smell and Intuition}

The sense of smell almost becomes a new faculty to penetrate the tangle of things. ${ }^{9}$

Helen Keller, The World I Live In

The sense of smell is intrinsically linked to instinct and intuition. The connection is made obvious when we use terms like "I smell a rat," or when we "smell danger" or "smell a storm coming." Engen writes, "What the nose knows, to use that popular expression, is to respond to chemical signals to keep us out of harm's way and to remind us of past odor experiences, both the foul and the fragrant."10 But not only can certain smells provide us with a warning sign, ${ }^{11}$ they can also provide a sense of comfort and subconsciously confirm the familiar or safe choice. Dogs are known for their characteristically bad eyesight and for their incredible sense of smell. Animals have a highly attuned sense of smell, and at

9 Keller 42.

10 Engen 120.

11 The nose can detect smoke, fire, gas leaks, for example; Helen Keller wrote that her nose could warn her of a coming storm. Also, odor is sometimes indicative illness and disease. 
some point in early evolution it is likely that humans did as well. The nose is an animal's most useful tool, used for detection of food, danger, mates, and kinship. The dominance of the nose for humans was likely usurped as our reliance on vision and higher-level thinking prevailed.

Author Malcolm Quantrill said of Finnish architect Reima Pietilä, "one is immediately aware of his [Pietilä's] innate 'animal' sense as he sniffs out 'the basic smell of architecture'." In conversation with Quantrill in 1979, Pietilä explained:

This 'sniffing sense' is a dog's way to experience the environment. ... A sniffer can move in the darkness and experience the invisible. The olfactory sense is a spatial sensing towards informality. Architecture can also be composed by this atmospherical method. ${ }^{12}$

Although the sense of smell has decreased in use in comparison to the sense of sight, Smell can be used in the design process to bring attention back to the qualitative aspects of spatial-perception.

Swiss architect Peter Zumthor writes, "The design process is based on a constant interplay of feeling and reason." Although a large component in design is based upon learned skills and contending with certain requirements or regulations, the architect will always have feelings, impressions, and instincts for a project that instinctually direct design decisions. As architects, "the essential substance of the architecture we seek proceeds from feeling and insight. Precious moments of intuition result from patient work."13

12 Malcolm Quantrill, Reima Pietila: Architecture, Context and Modernism (New York: Rizzoli, 1985) 179.

13 Peter Zumthor, Thinking Architecture, Second, expanded (Boston: Birkhauser, 2006) 21. 


\section{A Product of Our Environment}

People are a product of their environments, constantly being influenced by their surroundings. Similar to the way that one cannot breathe without smelling, no one is completely unaffected by their environment. ${ }^{14}$

The same is true in architecture. To quote Zumthor again:

We [architects] carry images of works of architecture by which we have been influenced around with us. We can re-invoke these images in our mind's eye and re-examine them. But this does not yet make a new design, new architecture. Every design needs new images. Our 'old' images can only help us to find new ones. ${ }^{15}$

As students of architecture we constantly use the dimensions of the spaces we work in as references for the imaginary spaces we create on paper. In my thesis studio, this is evident: my studio neighbour asks "How big is this room, again?" so that he may compare the space he is creating in his project with the size of the space he is sitting in. This not only provides him with a point of reference, but it also helps to define spaces that have the right "feeling." As an example, does the height of the ceiling and the width and length of the room have the "right" ratio? Does it have "good" feeling, or create the "right" or desired impression in the imagined space? This "feeling" is an intuitive awareness of the invisible qualities of a space, as well as an instinctive understanding of the impact of space and perception.

In Thinking Architecture, Peter Zumthor speculates whether his living and working environment has influenced his architecture. After deciding that it has, he realizes that not only has Graubünden influenced his work but so have many places (and things) that he has experienced. When designing something new, he reaches into his memory for the "images" of places and spaces that struck him:

14 This is observed in many ways, such as how children adopt certain mannerisms from their parents or can easily learn a new language.

15 Zumthor 67. 
Sometimes they come to me unbidden [...] At other times I summon them. I need them, for it is only when I confront and compare the essentials of different places, when I allow similar, related, or maybe alien elements to cast their light on the place of my intervention that the focused, multifaceted image of the local essence of the site emerges, a vision that reveals connections, exposes lines of force, and creates excitement. [...] So I immerse myself in the place and try to inhabit it in my imagination, and at the same time look beyond it at the world of my other places. ${ }^{16}$

Effectively Zumthor tries to superimpose his remembered places upon the present. In this he reveals that remembered places and experiences are equally significant as one's present surroundings in the conceiving of architecture. This includes the intangible qualities of a place like smells, "feelings," atmospheres as well as physical, measurable characteristics. 
$4_{\text {This Project Stinks }}$

Introduction to the Project of Architecture

The previous chapter set out to explain the importance of smell in the experience of a place, discussing the way that odor is linked to memory, instinct and intuition. The role of scents in this project is not to forcibly influence a person's behaviour, nor is it to overwhelm the senses with a smorgasbord of smelly surfaces. Through the design of an office for architecture, 25 REUBEN, the purpose of this project is to permit the smells of certain moments or details throughout the building to be absorbed by the subconscious and permeate into the intuitive aspects of the design process. In most cases, the smell is inherent to the nature of the material (smoked woods, for example) as opposed to being fragranced afterward through a scented polish or other finish. Interior details will mostly focus on surfaces that the architects will come into direct contact with through the touch of the hand. Landscaping and aromatic plants characterize the exterior details, as well as local smells that are carried by the wind, or accentuated by the rain, the seasons, and other weather. As Helen Keller observed,

Each season has its distinctive odours. The spring is earthy and full of sap. July is rich with the odour of ripening grain and hay. As the season advances, a crisp, dry, mature odour predominates, and golden-rod, tansy, and everlastings mark the onward march of the 
year. In autumn, soft, alluring scents till the air, floating from thichet, grass, flower, and tree, and they tell me of time and change, of death and life's renewal, desire and its fulfilment [sic].

As filters between the outside and inside air, the thresholds (doors and windows) remain odor neutral so as not to alter the distinct smells of the area characteristic to each season.

\section{Adaptive Reuse of the Kemptville Armoury}

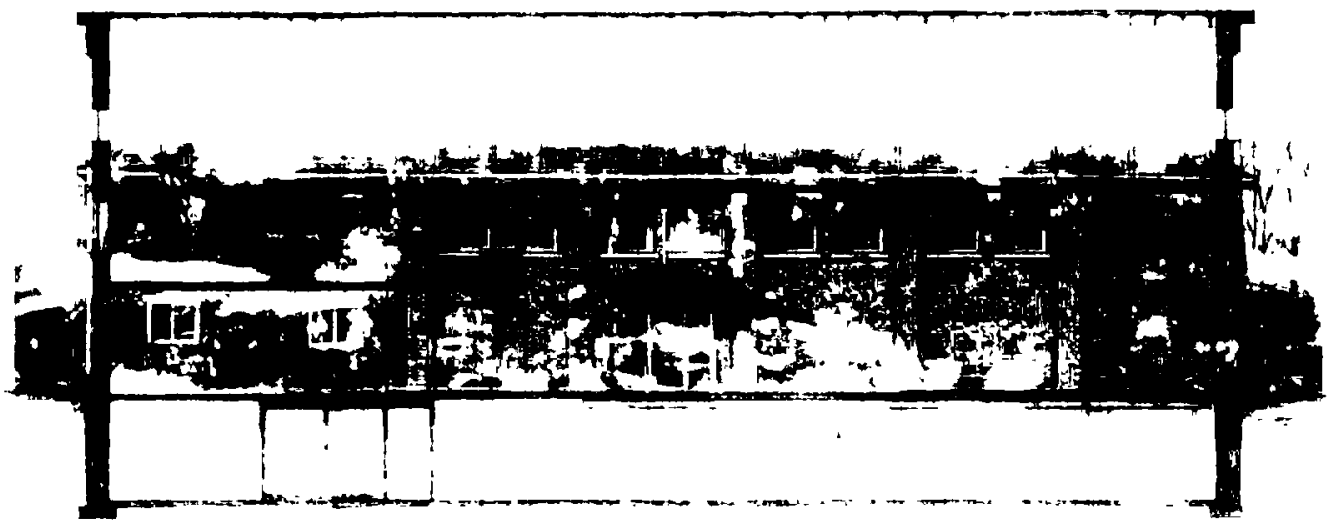

Figure 12. Southwest elevation of Kemptville Fire Hall with section overlay

In keeping with contemporary adaptive reuse ideology, the former Kemptville fire hall at 25 Reuben Crescent will be transformed into the office for architects. Built in 1915 , the original use of the single storey structure was an armoury for Canadian military training and munitions storage. The building served as the town's fire hall from 1969 until September 
2009, when the fire department took up residence in a newer, larger facility. ${ }^{2}$ The armoury is located in Old Town Kemptville, near to the Kemptville Creek wetland, and across from the municipal Riverside Park. In July 2010, the Kemptville Armoury was recommended for a heritage designation under the Ontario Heritage Act.

Prior to the suggestion of the official heritage status, the Armoury was still considered to have historic and sentimental value in the community. Regardless of the alterations that changed the building from a drill hall to a fire hall, the Armoury has served as a prominent part of the built community. It is an example of a small-sized standard-plan armoury, in the Regency Revival style typical of some armouries also built during the pre-WWI military building campaign. ${ }^{3}$ The red brick walls are approximately 14 " deep with engaged pilasters that visually divide the side façades into seven bays and the front and rear façades into three. A photograph taken prior to the 1933 fire shows the original parapet and corbelling that were altered after the fire. The designation will

2 In late 2009 the municipality of North Grenville declared a surplus of "dormant" municıpal buildings. A report identified six buildings within the greater Kemptville area, including the newly vacant Kemptville Armoury. The planning department identifies the importance of the heritage buildings to the community as well as the cultural identity of the township. The most current decision is that the municipality will use the proceeds from the sale of four of the buildings (including the Armoury) for care and mantenance of the two to be retained by the municipality. Ashley Kulp "Council holds firm on fate of surplus buildings..." 1 /uly 2010.

3 The Department of Militia and Defence oversaw the consiruction of armouries at this time.

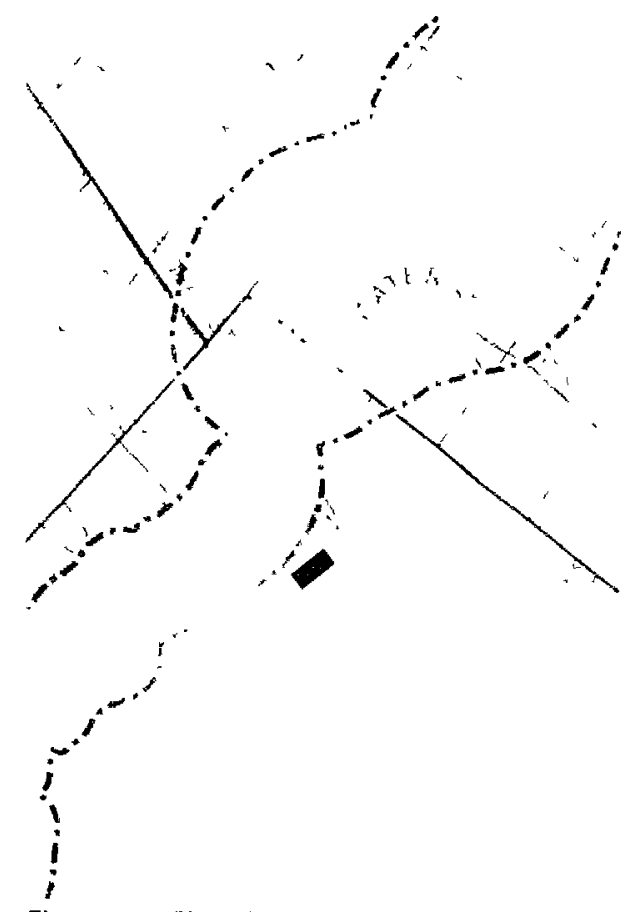

Figure 13. Site Map

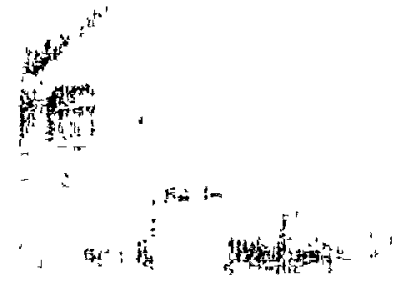

Figure 14. The Kemptville Armoury prior to 1933 fire.

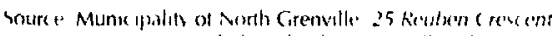
2010 Report) Origenal photo by the kemplville Adhance. (newy)aper). 
protect the low-pitch gable roof, the heavy-duty brick wall and corbelling of the eaves, and all of the original windows.

The design strategy for 25 Reuben, detailed in the Specification in the following chapter, will respect the new designation as well as some of the alterations that were made when the building was converted to the fire hall.

\section{ReubeN}

25 REUBEN is an office for up-and-coming architects, without the financial means to start up their own practice but who are eager to be a part of an innovative work environment. It functions similarly to a studio environment in that architects have their own workstation with lockable storage and sharing ideas is encouraged. The office provides shared amenities such as copy, fax, and print services, access to the private meeting room, Internet and telephone, as well as washrooms, showers, and kitchen facilities. A shared materials library and a reference library are what make this office unique to architects. Unlike most architecture offices, the materials library is not relegated to a back room; it is the prominent feature within the main studio space. Acting as both storage and display for materials and samples, the library takes shape under a long smoked-oak tabletop situated centrally, and which also provides a communal work surface, as well as a place for impromptu conversation and brainstorming. Furthermore, the office encourages a cross-section of experience among the architects. In this way the less-experienced architects can seek the guidance and expertise of the more senior architects, and one generation can be inspired by the knowledge of another. Lastly, although the office design is tailored for architects, the office is open for anyone from related fields that might benefit from this type of working environment and who could reciprocate in idea-sharing. 
25 Rubav is based upon the Centre for Social Innovation (CSI) model. Located in a refurbished factory at 215 Spadina Avenue in downtown Toronto, CSI is an example of modern workplace with an avantgarde philosophy. Occupying two of the building's four floors, CSI provides a multi-disciplinary, inspiring environment for established businesses as well as entrepreneurs. Members can rent a permanent workupace, an office, or just a "hotdesk" (temporary workspacel for a tew hours per week. In this model, all traditional office amenities (copiers, printers, use of meetung rooms, etc.) are included in the rental cost or on a pav-per-use system. The CSI philosophy is built upon the ideas of "co-loxation", "coworking" and "incubation", which they have described an support that is given to early-stage projects and organizations.' CSI provides space to meet, to work, and to connect, by creating an environment that fosters social innovation and cross-disciplinary interaction. Members of the CSI community claim that the most important experience of the social work environment is the opportunity to exc hange ideas and contac ts with other members. "

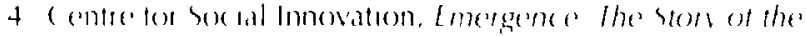

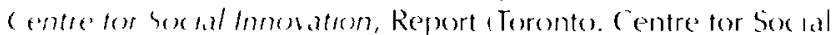
Inmovattom, 2010) 22-23.

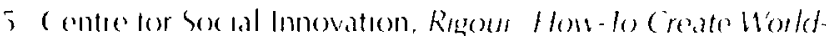
(hrmging spares, Report (Toronto: (entre tor boc hal Innovation, $2(1) 1(1) 10) 3$.
}

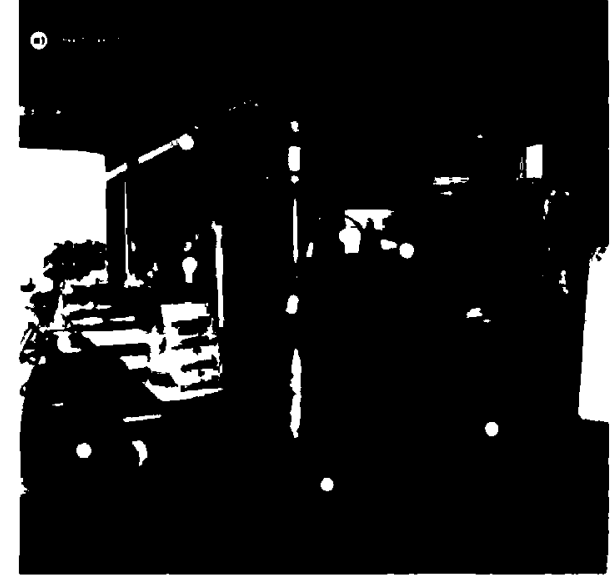

igure 15. Centre tor boc lal Innoxation shared spaces.

1 Photo Copung and Pinting

2 High-Speed Internet

3 Far Machines

+ Mallboxes

5 Kitchen Facilition

6 Meeting Rooms

$\rightarrow$ colferes

8 Securits

9) leanung

10 NV Equpment 


\section{The Specification}

The Project of Architecture presented in the next chapter is the culmination of the ideas and theory discussed in this thesis, composed in the style of a Specification document. The goal of the Specification is to capture and present both the visual and intangible qualities desired for the Office for Architects through the concurrent use of text and drawing. The synthesis of the two conventional media is furthered with the use of colour, inspired by Luca Turin's observation discussed in Chapter 2. In addition to smell, the modification of the conventional specification can also call attention to the other important factors that affect the quality of spaces, such as context, climate, the air and weather, and even the people that inhabit those spaces. This means that the Project of Architecture, is not only the design of a building that incorporates "smelly" details, but is also the manner in which the ideas are presented: the Specification.

\section{An Architectural Mise en Abîme}

I have a collection of smelly objects next to my drawing board. While I think, write and draw this project, I smell the materials that make up the surfaces in the spaces I am conceiving. These smells help me to imagine how the spaces could feel. In the same way that I am influenced by my surroundings and previous experiences, the environment that I have created will influence the architects who work in that office. Although this might be a rather presumptuous hypothesis, I envision a sort of architectural mise en abîme: a compounding of inspirational details. I am influenced by my environment. I design an office for architects. 
The architects working there are influenced by their environment (which includes the one that I have created for them). In turn, they design other buildings that influence other individuals. Should one of these architects design yet another architecture office, the pattern continues.

But all this begins with the initial project, which is backed by the desire to fight for Smell and other senses to be returned to architecture and the design process. For this reason, the architect's office was purposely chosen as the program to assist in a further dissemination of the ideas set forth in this thesis which infuse the thinking and making of architecture with the invisible qualities of Smell. The following project, which details the conversion of the former Armoury into the office for architects in the format of a specification, demonstrates one possible way to reintegrate Smell into architectural consciousness. 


\section{Project of Architecture}
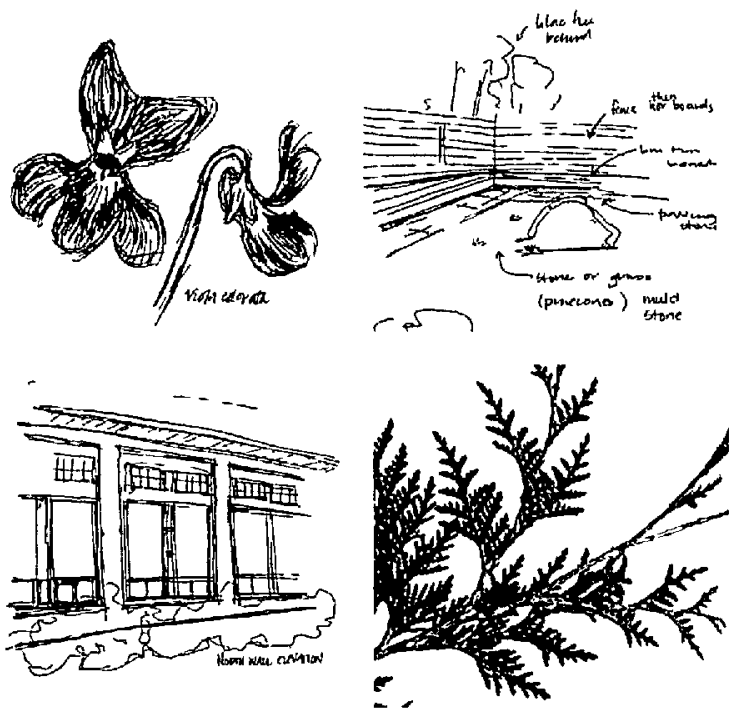

Specificatıon for 25 Reuben Crescent, Kemptville ON 


\title{
SPECIFICATION
}

\author{
prepared for \\ ADDITION AND RENOVATION TO \\ 25 REUBEN CRESCENT \\ KEMPTVILLE, ONTARIO \\ KOG 110
}

Issued: September 21, 2010

prepared by

Katelyn Lucas, B. Arch. St. (2008)

Ottawa, Ontario 


\begin{tabular}{|c|c|}
\hline Ceneral Index & 00 \\
\hline \multicolumn{2}{|l|}{ Division A - Summary of Work } \\
\hline Section 1 - General & 3 \\
\hline Section 2 - Design Intent & 4 \\
\hline \multicolumn{2}{|l|}{ Division B } \\
\hline Section 1 - Landscaping & 6 \\
\hline Section 2 - Concrete & 7 \\
\hline Section 3 - Stone & 7 \\
\hline Section 4 - Exterior Carpentry & 7 \\
\hline Section 5 - Interior Carpentry and Millwork & 8 \\
\hline Section 6 - Openings & 8 \\
\hline Section 7 - Flooring & 8 \\
\hline Section 8 - Wall Finishes & 9 \\
\hline \multicolumn{2}{|l|}{ Division C } \\
\hline [ 001 ] EAST GARDEN & 10 \\
\hline [ 002 ] PARKING, PLANTERS AND HERB GARDEN & 13 \\
\hline [ 003 ] WEST GARDEN & 14 \\
\hline [ 101 ] VESTIBULE & 16 \\
\hline [ 104 ] STUDIO & 19 \\
\hline [ 105 ] RESOURCE LIBRARY & 22 \\
\hline [ 106 ] COFFEE ROOM & 23 \\
\hline [ 109 ] REAR ENTRY & 24 \\
\hline [ S01 ] STAIR - ASCENT & 26 \\
\hline [ S02 ] STAIR - DESCENT & 26 \\
\hline
\end{tabular}




\section{Section 1 - General}

\subsection{General}

a. The mention hereinafter of any article, material, operation or method, requires that the Contractor shall provide each item listed of the quality noted and perform each operation prescribed according to conditions stated, provided therefore all necessary labour, equipment and incidentals for the project known as 25 REUBEN or Architect's Office.

b. The following Specification will detail the scope of work for the conversion of the former Kemptville fire hall located at 25 Reuben Crescent to an office for architects.

c. Any work marked NIC (Not in Contract) means that the work is not part of the base contract, but appropriate preparations are still to be performed to accommodate this work at a later day; either by the Owner or under a separate contract.

\subsection{Definitions}

a. In this Specification, all reference to the following names shall mean or refer to:

i. Owner

ii. Architect

iii. Construction Manager

iv. Contractor
25 REUBEN

Katelyn Lucas, B. Arch. St.

You, the reader of this document
25 Reuben Cres. Kemptville ON

432 Azrieli Pavilion 1125 Colonel By Dr. Ottawa ON

Carleton University Ottawa ON

TBD

\subsection{Documents}

a. The Construction Manager and Contractor(s) are provided with both Drawings and the Specification. All Drawings and Specifications shall be interpreted together to execute the intentions of the design. In the case of discrepancies between drawings, those of larger scale, or those of a later date shall govern. Should the specifications conflict with the Drawings, the Specifications shall govern. In all other cases, the 
Construction Manager should contact the Architect for further instruction and the issuance of Addenda, Change Orders, and other supplementary instructions.

b. TheSpecification (thisdocument) isformatted similarlytocontemporary Specifications layouts (National Master Specification [NMS]) however certain categories and information regarding particular building components that are typically covered have been omitted, condensed, or otherwise altered for the purpose of this thesis. Furthermore, as shown in 00 General Index, this Specification details the project in three (3) parts: Division A outlines the overall strategy and intent of design; Division $B$ is organized by typical building materials and methods; Division $C$ defines in more specific detail the materials, methods and other instructions unique to each area.

\subsection{Project Meetings}

a. Project meetings shall be regularly scheduled between the Construction Manager, Architect and/or Owner. Rich, earthy and full-bodied coffee to be served, brewed from Arabica coffee beans with distinct but pleasant sharpness. To achieve best flavour and aroma: Grind roasted beans immediately before brewing. Use cold water for brewing. Do not remove carafe from machine until full the last drop of coffee has fallen to ensure even distribution of flavour. Minutes will be recorded and distributed to all attendees within one week of the meeting.

\section{Section 2 - Design Intent}

\subsection{General}

a. The overall strategy is to provide the end-user with certain experiences along the architectural promenade, or procession through the property and building. Certain moments are marked by fragrant details that persist beyond the visual level. Care must be taken to ensure that certain components are situated in accordance with the Documents so as to harmoniously complete the experiential, atmospheric and invisible aspects of the space with respect to other components.

\subsection{Existing Building Shell}

a. The design strategy detailed in the following specification will consider the prospective heritage designation which will likely protect the existing building shell, significant architectural features, and selective alterations that were made to the building when it was converted from a drill hall to the fire hall. For further 
information refer to North Grenville Report detailing the recommendation for the heritage designation.

b. Any alterations to the building façade will be minimally invasive with the exception of the installation of new openings on the northwest elevation to gain more natural light within the Studio. "'There has to be lots of light' - light is how you achieve openness."1

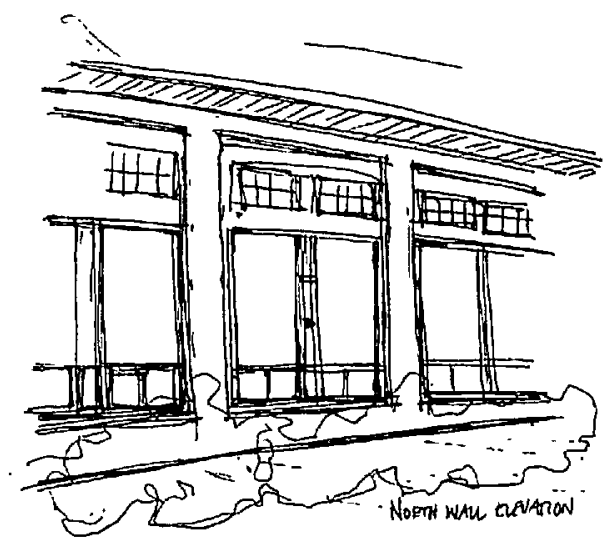

\subsection{Interior Strategy [Openness]}

a. The overall design of the interior will take advantage of the existing openness of the former drill hall. ${ }^{2}$ Selected interior partitions to be removed on both floors to add to feeling of openness. Work to include removal of wall on the second floor to create an open mezzanine level, and the removal most existing walls on the ground floor. Partitions to be maintained or replaced with glazing between the meeting room, coffee room and studio.

b. Other interior construction to include: the installation of showers and renovation of washrooms in the basement level.

\subsection{Scope of Exterior Work}

a. Exterior work to include but not limited to, demolition of existing shed at the rear of the building, partial demolition of its existing concrete slab; asphalt paving to be demolished and removed from site; new landscaping including installation of concrete sidewalk and unit pavers, exterior carpentry work, and the planting of greenery.

\section{END OF DIVISION}

1 Centre for Social Innovation, "Emergence" 54.

2 Openness is a key factor in the success of the Centre Social Innovation as it contributes to the health and wellbeing of members (air circulation and access to natural light), as well as office safety and security. 


\section{Section 1 - Landscaping}

\subsection{Work Included}

a. All work included in this section relates to the hard-scaping and soft-scaping of the exterior environment at 25 Reuben Crescent. This includes, but is not limited to: the installation of curbs and sidewalks; demolition and removal of existing asphalt; placing of topsoil and sod; planting of trees, shrubs, and other fragrant greenery; construction of fencing and gates; construction of pergola, benches and planters.

\subsection{Related Sections}
a. B2 - Concrete
b. B3 - Stone
c. B4 - Exterior carpentry

\subsection{Quality}

a. Proceed with planting and sodding during suitable weather conditions and in accordance with good horticultural practice. Use trees, shrubs, mulches, and other fragrant plants only of good quality.

\subsection{Products}

a. Topsoil: Fertile and friable sandy loam with a min. $2 \%$ organic matter content. Topsoil may be taken from existing stockpile provided it has fresh, earthy scent, free of foul chemical odor indicating contaminants.

b. Sod: Certified No. 1 grade cultivated turf grass sod with a composition of $50 \%$ Kentucky Blue Grass and 50\% Merion Blue Grass. Sod must have strong, fibrous root system and be free of stone and burned or bare spots.

c. Trees, Shrubs and Other Plantings: All plant material must conform to the type and sizes shown on Drawings. Flower or shrub beds to have $450 \mathrm{~mm}\left(18^{\prime \prime}\right)$ topsoil. Ensure width of all planting excavations in $300 \mathrm{~mm}$ (12") greater on all sides of the width of the root ball. Plant plumb. Backfill with rich, earthy planting soil, and firmly tamp each layer to eliminate any air pockets and ensure that plant retains its orientation. 


\section{Section 2 - Concrete $^{3}$}

\subsection{Work Included}

a. This work includes the supply and install of cast-in-place concrete footing, curbs and sidewalks, complete with steel reinforcing when necessary, saw-cuts joints, and expansion strips where indicated. Concrete NOT to be poured in weather colder than 5 degrees Celsius. Adequate measures to be taken to protect concrete from exposure to freezing temperatures for a minimum of one week after pour.

b. Cure and seal finish for shed building. Broom finish all other exterior concrete.

c. Slope to drain towards mulch beds.

\subsection{Products}

a. Crush and reuse concrete from demolition of existing slab for new $125 \mathrm{~mm}\left(5^{\prime \prime}\right)$ thick for sidewalks. Minimum $125 \mathrm{~mm}\left(5^{\prime}\right)$ compacted granular 'A' fill below sidewalks.

\section{$\underline{\text { Section } 3-\text { Stone }^{4}}$}

\subsection{Work included}

a. Stone pavers, bedding sand, joint sand, to be supplied and installed as indicated in Drawings, joints filled with sand as per typical unless otherwise noted on Drawings or in Division C.

\section{Section 4 - Exterior Carpentry ${ }^{5}$}

\subsection{Work Included}

a. Construction of cedar fence, gate, benches, pergola, and planter boxes.

\subsection{Products}

a. Wood: Premium grade White Cedar, unless otherwise noted. Smell of cedar to be typically sweet, resinous, and reminiscent of the cottage, camping, or a walk in the forest. All boards laid horizontally to have $4 \mathrm{~mm}\left(3 / 16^{\prime \prime}\right)$ spacing to ensure proper

3 National Master Specification (NMS) 321614.

4 NMS 321310.

5 NMS 323700 . 
drainage.

b. Hardware: All hardware to be heavy-duty galvanized steel, type as indicated on Drawings.

\section{$\underline{\text { Section } 5 \text { - Interior Carpentry and Millwork }}{ }^{6}$}

\subsection{Work Included}

a. Supply and install as shown on drawings: washroom vanities, cupboards, countertops, shelving, stair treads and risers.

\subsection{Products}

a. Wood: High quality maple or birch wood, unless otherwise noted on Drawings or in Division C.

b. Hardware: Refer to Drawings.

\section{Section 6 - Openings}

\subsection{Work Included}

a. Interior doors, frame and trim. Exterior doors and windows, frame and trim. Installation of specialty doors.

\subsection{Other Instructions}

a. All exterior doors and windows to meet conform to regulations governed by code. Openings required to be unscented to permit the untainted passage of air from exterior to interior and vice versa. Glazed openings to contribute to the feeling of openness (outlined in A2.3).

b. For specialty openings refer to Division $C$ for detailed instructions.

\section{Section 7 - Flooring}

\subsection{Work Included}

a. Finish polished concrete flooring, supply and install of carpet and ceramic tile. Refinishing of existing hardwood flooring. 


\subsection{Work by Others}

a. Supply and install polished concrete topping and in-floor radiant heating.

\subsection{Products}

a. Carpet: Natural fibre (coir, jute or sisal) woven textile floor covering by Merida Meridian with bound edging; Carpet base: $100 \mathrm{~mm}$ high with bound edging only where indicated. Refer to Division $C$ for detail.

b. Porcelain tile: $300 \times 300 \mathrm{~mm}\left(12 \times 12^{\prime \prime}\right)$ selected from product manufacturer approved by Architect. Install by supplier; $6 \mathrm{~mm}$ spacing; typical square grid, unless otherwise shown. Colour and model TBD.

\subsection{Other Instructions}

a. For existing hardwood flooring. Remove existing carpeting, under pad and/or tile where the refinishing of existing hardwood flooring is indicated. Sand, clean, and seal with wax. Polish monthly, more frequently with higher traffic.

\section{$\underline{\text { Section } 8 \text {-Wall Finishes }}$}

\subsection{Work Included}

a. Odor-resistant, mildew resistant, and zero to low VOC paint (such as Benjamin Moore Eco Spec Silver Interior Latex Flat Finish).

b. Do not paint when temperature of air and surface is below $10^{\circ} \mathrm{C}\left(50^{\circ} \mathrm{F}\right)$.

\subsection{Colour}

a. Colour tint to be determined on a room-by-room basis.

END OF DIVISION 


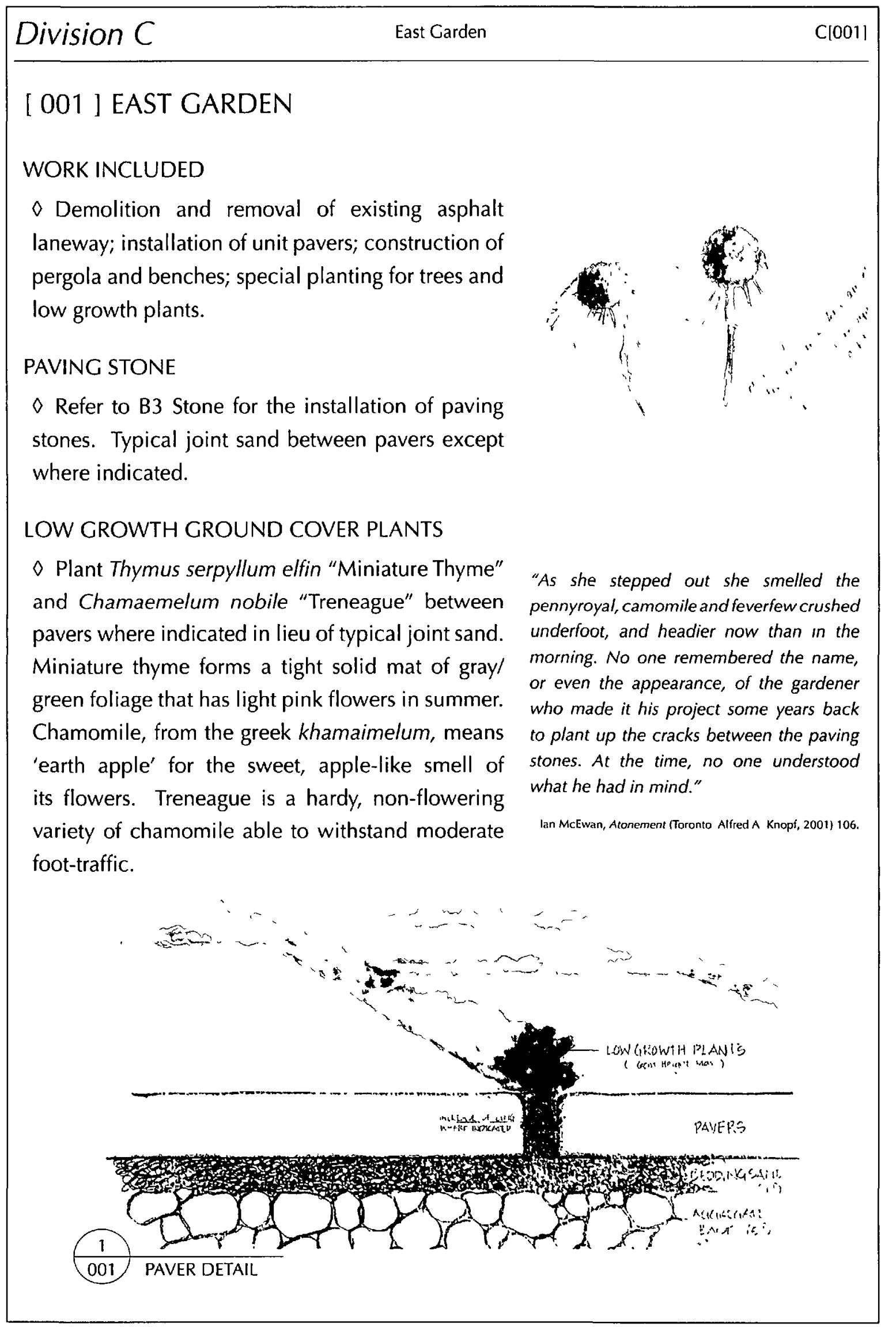




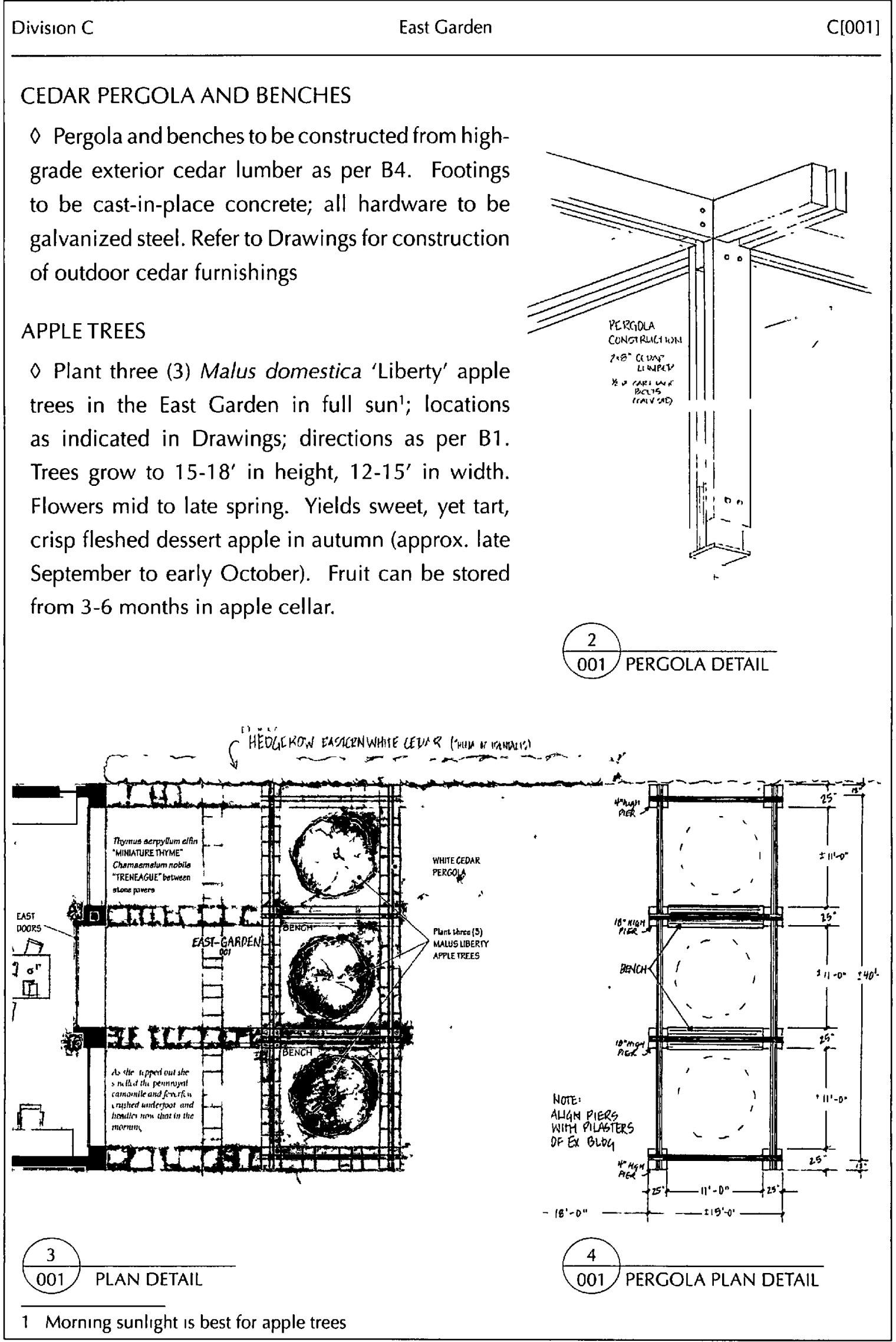




\begin{tabular}{lll}
\hline Division C & East Garden & Cl001] \\
\hline
\end{tabular}

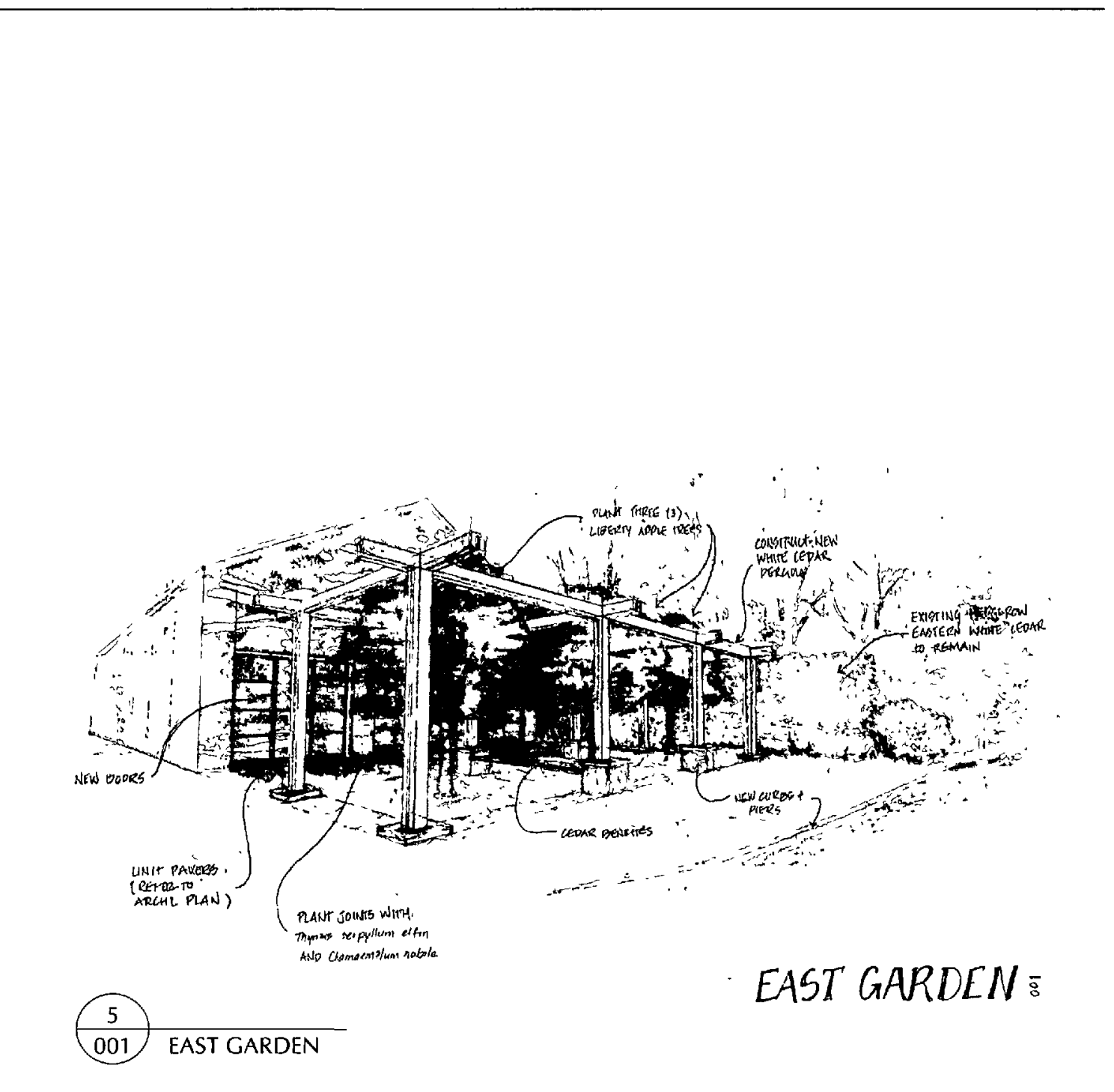

Intuition Prevails! When I began designing the outdoor landscape for this project, a 'feeling' led me to place apple trees on the east side of the property in a line perpendicular to the existing hedgerow of Eastern White Cedar. While researching companion plants for the Herb Garden, I came across the disease Cedar-Apple Rust that damages the apple tree and hinders the production of fruit. In a panic I began to look into this disease further and later discovered that it affects junipers and other red cedars, meaning that white cedars are in the clear! I felt a calming sensation as satisfaction swept over me-my original intuitions were in fact correct. 


\section{[ 002 ] PARKING, PLANTERS AND HERB GARDEN}

\section{PARKING SPACES}

Situated along the southern property line, oriented towards the municipal parking and Sunday Farmer's Market.

\section{PLANTERS \& HERB GARDEN}

$\diamond$ Along southern edge of property line construct wood planters in accordance with Drawıngs. Fill planter with soil and plant herbs in locations as indicated on Drawings.

$\checkmark$ Herbs can be picked at the end of the day, taken home and incorporated into dinner.
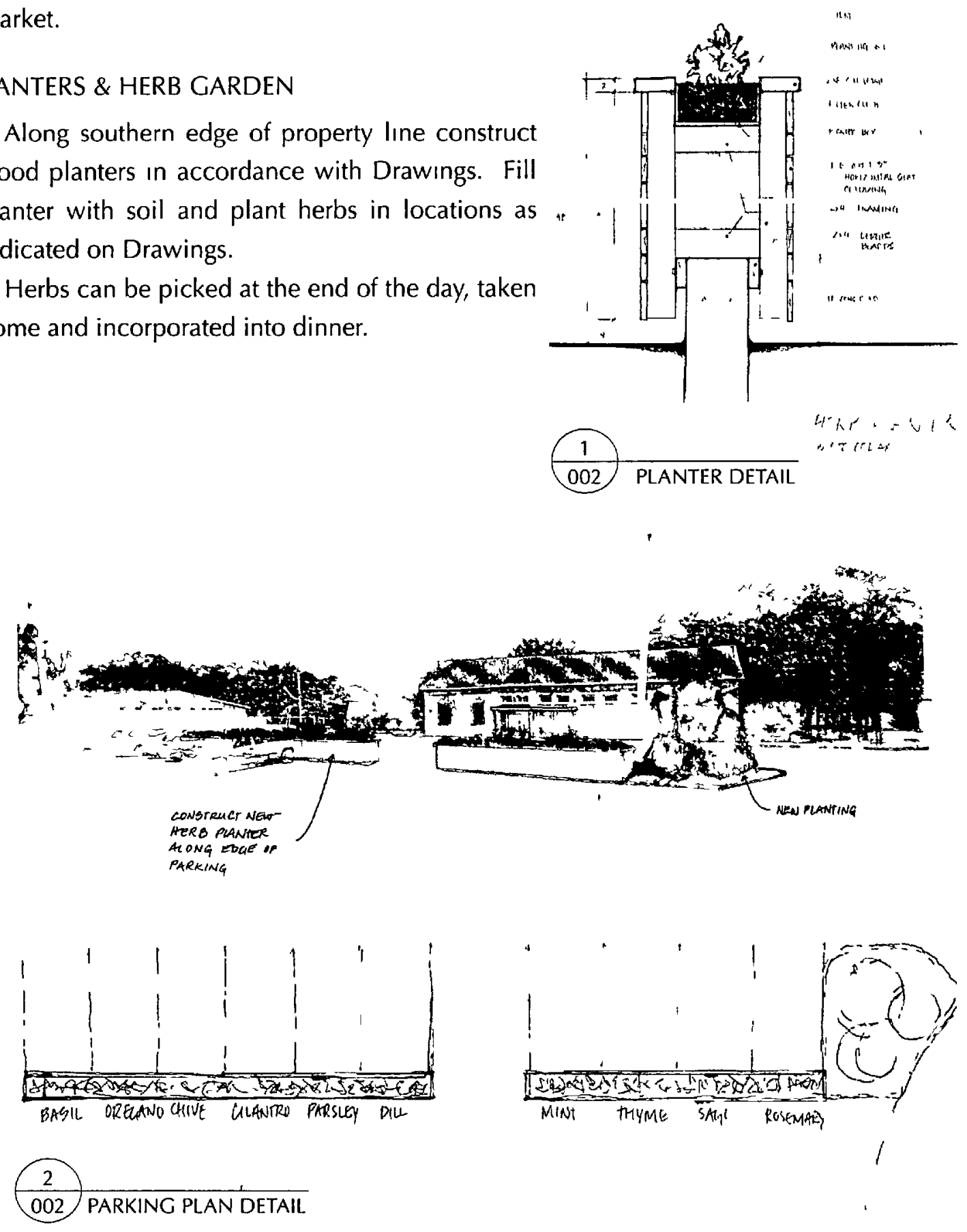


\section{| 003 | WEST GARDEN}

\section{DEMOLITION}

$\checkmark$ Demolish garage and part of existing concrete slab to extents as shown on Drawings. Part of existing concrete slab to remain as dining patio and floor of future utility shed (NIC).

\section{LANDSCAPING}

$\checkmark$ Supply and install new concrete walkway and stoop at rear door. Refer to B2 for general supply and installation requirements. Refer to Drawings for location and dimensions.

$\checkmark$ Construct new privacy fence and gate as indicated in Drawings. Horizontal cedar slats to be continuous along length of fence, including gate. Maintain $150 \mathrm{~mm}\left(6^{\prime \prime}\right)$ gap between ground and bottom of fence.

$\checkmark$ Plant new pine trees and ornamental shrubs in accordance with B1. Location of plantings as ",.., indicated on Drawings.

$\checkmark$ Special Planting Instruction: Vaccinium corymbosum 'Blueray' blueberry bushes to be planted beneath kitchen and meeting room windows on west façade. Add pine needle or cedar mulch to top of soil to adjust $\mathrm{pH}$ levels of soil for best results. Flowering occurs May-June when small white-pinkish flowers emit an intoxicating jasmine-like scent. June-August yields large and firm dessert-quality berries, excellent for pies, topped on yogurt or served alone. Each bush will grow 4 to $6^{\prime}$ in height and diameter. Prune after first winter, taking care not to trim more than one third of bush.

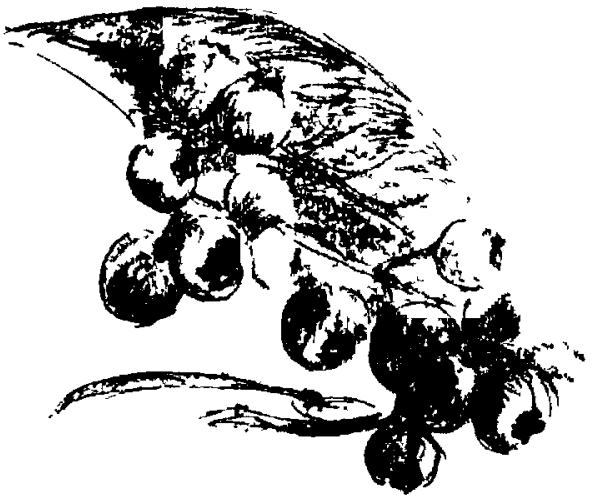




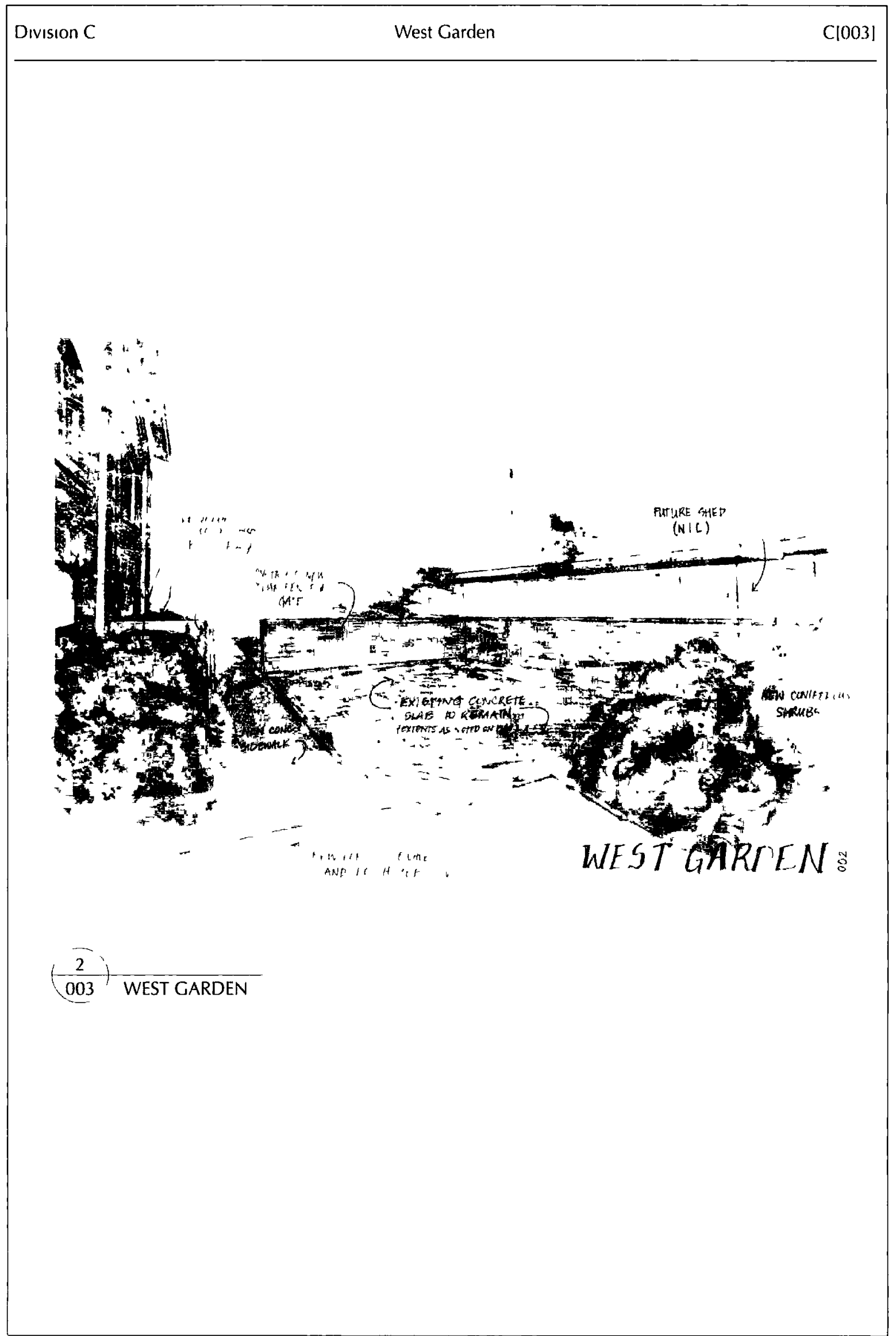




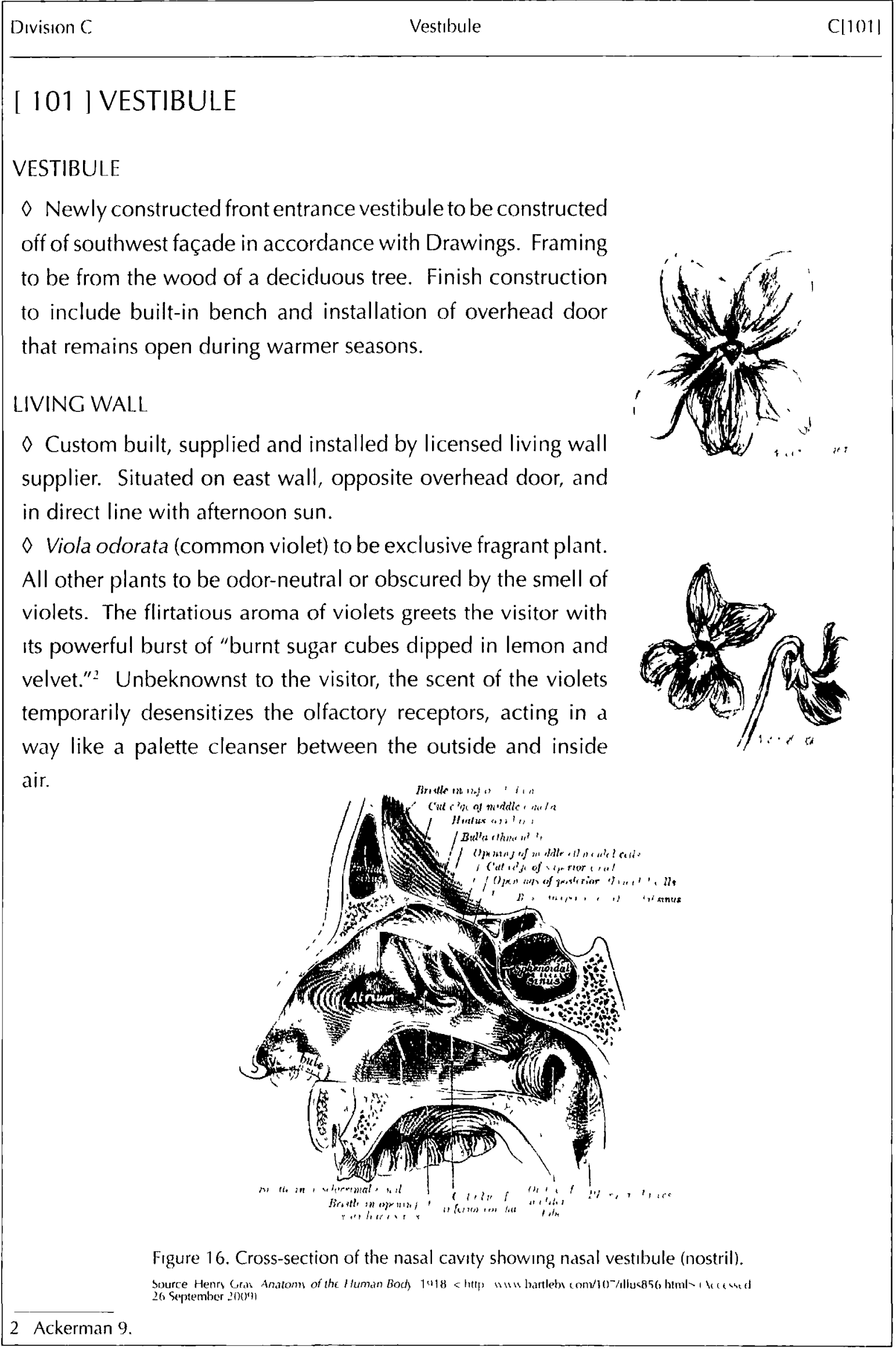

specitrotion 16 


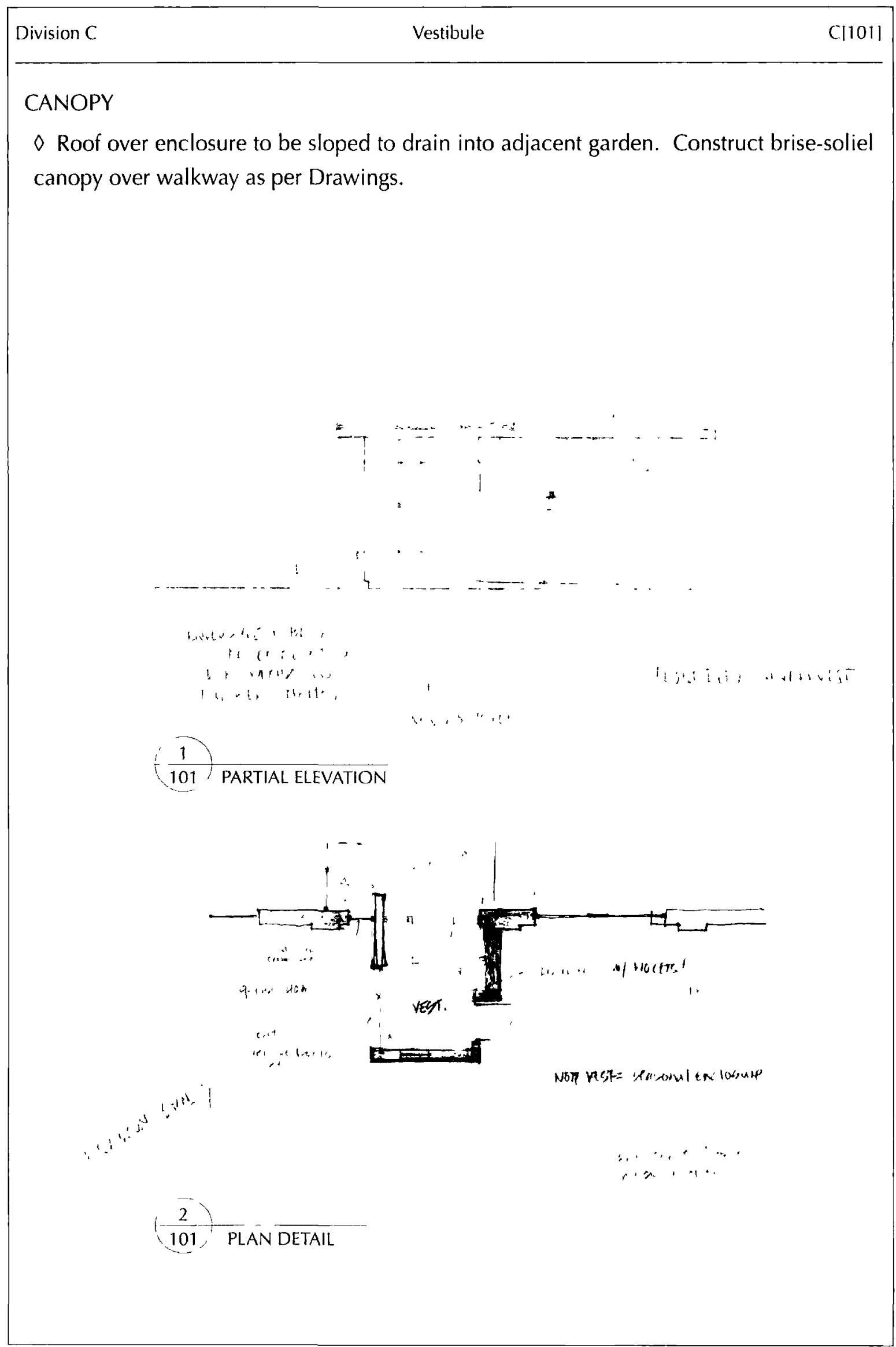


This Project Stmks 5

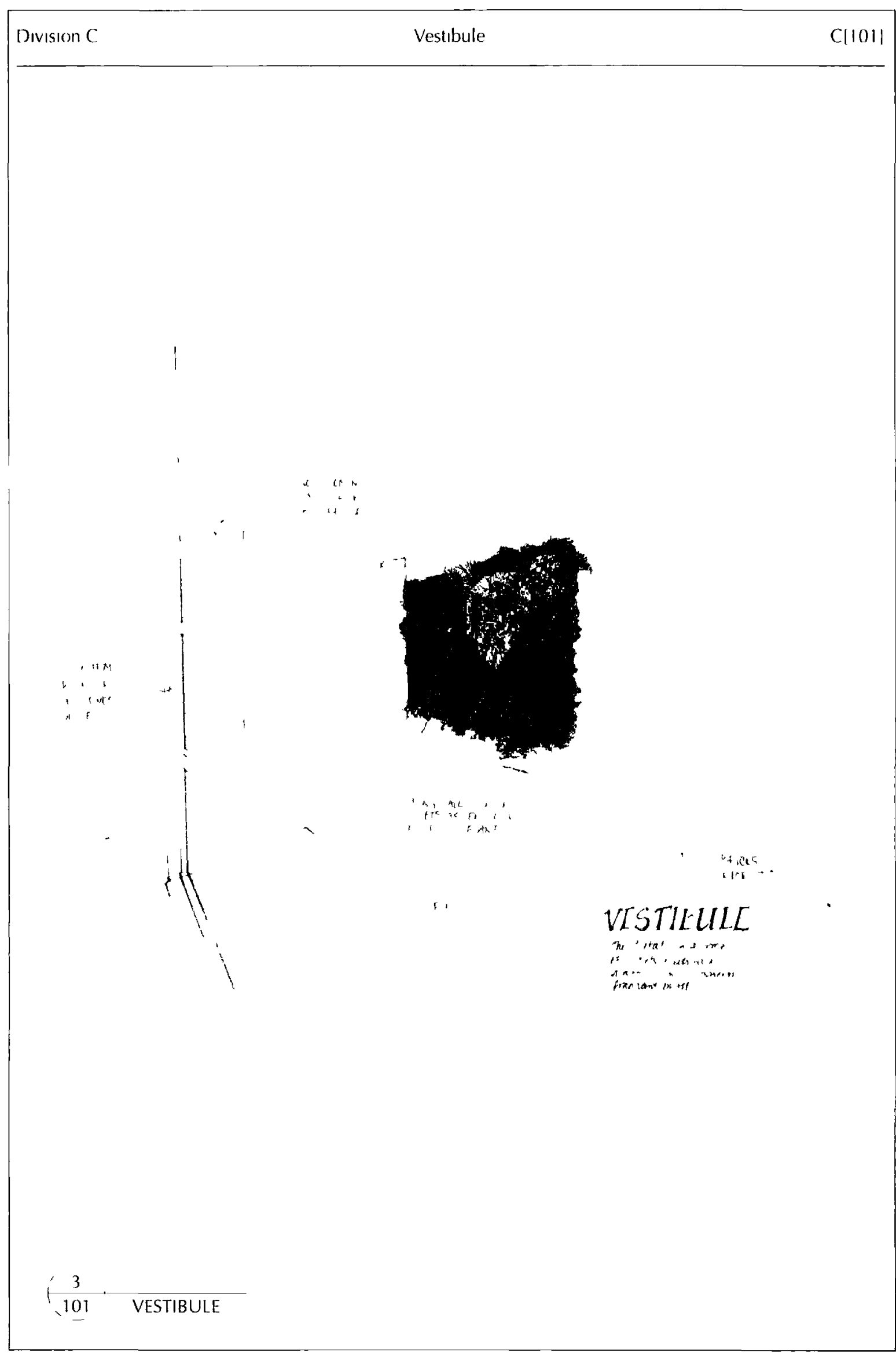




\section{Division C \\ [ 104 ] STUDIO}

Studio

WALLS

$\checkmark$ Exıstıng walls to be cleaned and repainted with Low VOC paint (see B8) Colour chorce to compliment the smell of the smoked oak surface of the materials and resources table. This could be an off-white or taupe with earthy accents that permit the smell to stand out. It is best to avord pink, pastels and other vibıant colours so as not to draw visual attention to the wall and suppress the presence of the aromatıc qualitıes.'

\section{MATERIAL RESOURCES TABLE}

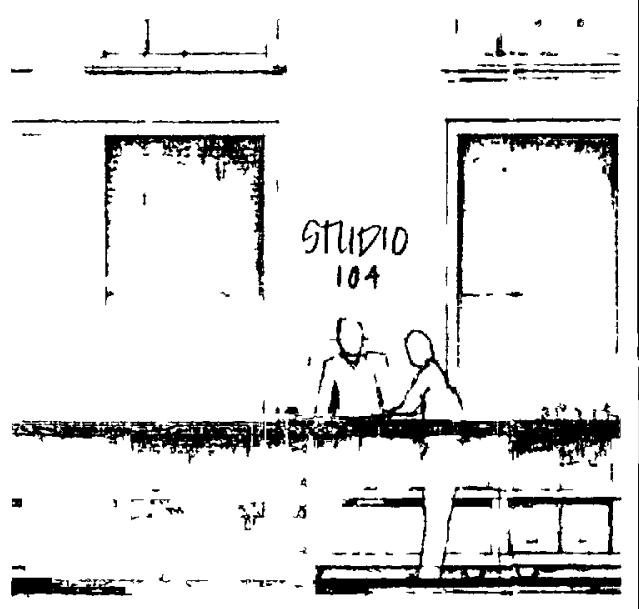

$\checkmark$ Special Construction. Located in the centre of the studio, this 32-foot long table provides a point of convergence for any and all projects happening in the office, doubling as storage and display for material samples and a communal work area. Here employees can unroll drawings and discuss projects and details with colleagues Samples

3 A study conducted at Montclaır State University concluded that colour enhances the intensity of odor The study, "Color Enhances Orthonasal Olfactory Intensity and Reduces Retronasal Oltactory Intensity," compared the intensity of odors that were smelled or tasted from combinations of coloured or colourless and scented or scent-free lıquids The conclusion was that the odor was percesved to be more intense in the coloured and scented solution (reter to Koza, Brian J et al [2005|) The wall colours tor the otfice will be selected based on this subjective principle colour compliments the odor of the smoked oak centerpiece

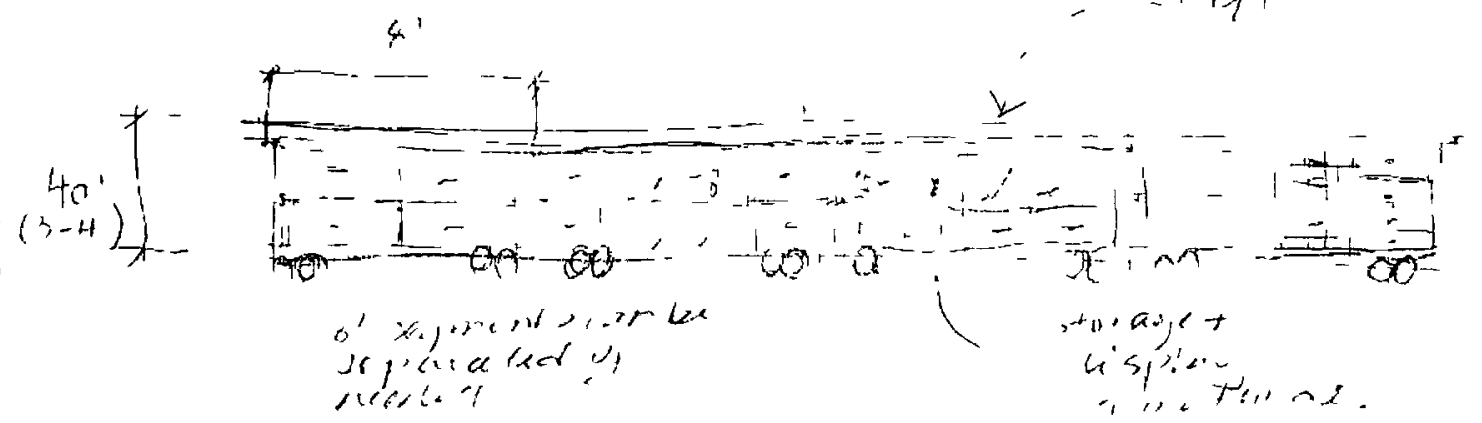




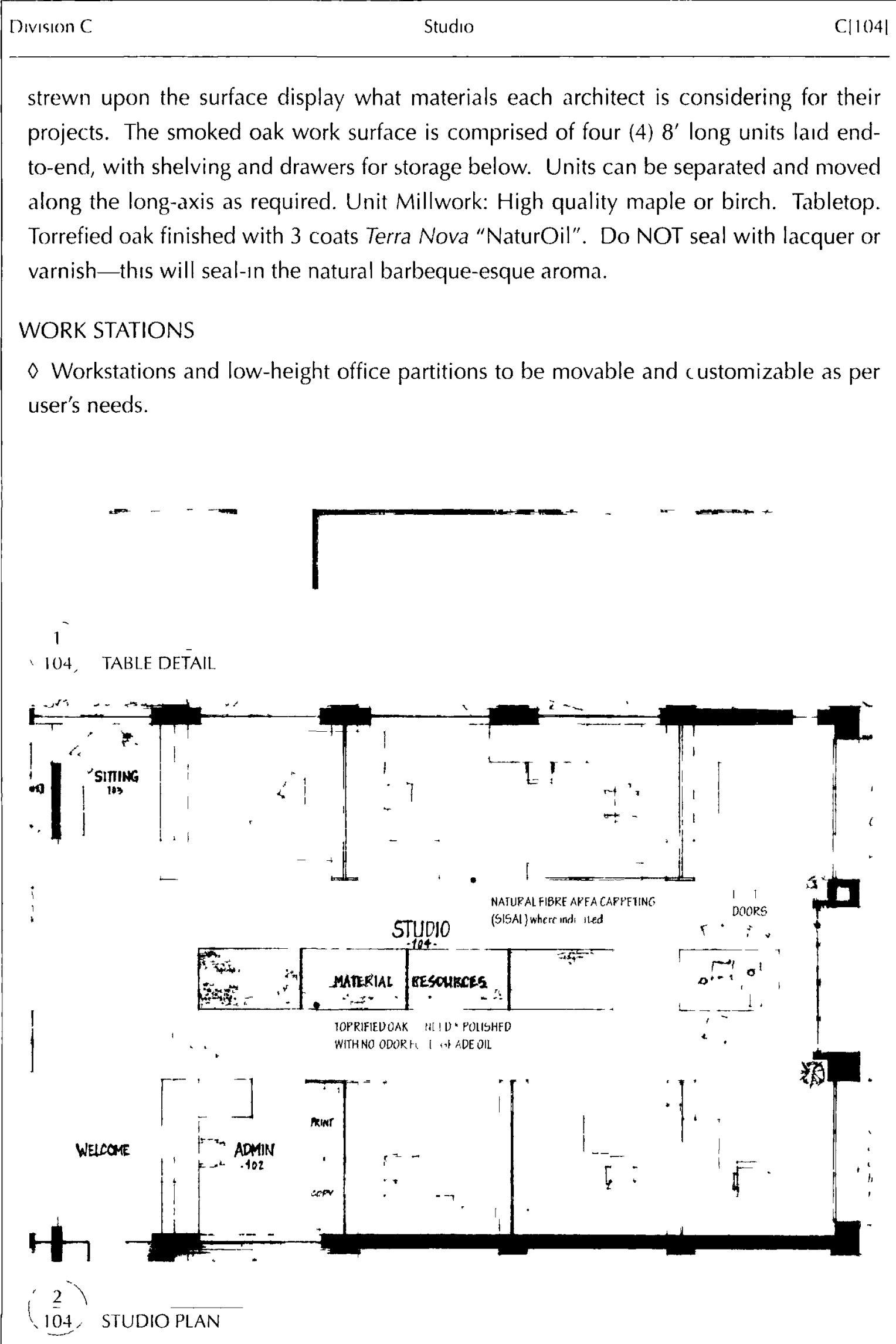




\section{EAST DOORS}

$\checkmark$ Special Construction. Doors to be divided into four horizontal segments that slide along vertical track to open at varying heights. This permits user to control the amount and height of airflow desired depending on the time of day, season, or wind direction. A small crack at the bottom of the door during a summer shower admits a refreshing coolness and earthy and wormy scents that remind of the textures of the ground beyond. When all segments are raised, door can be opened fully in order to pass from the Studio to exterior paved area.

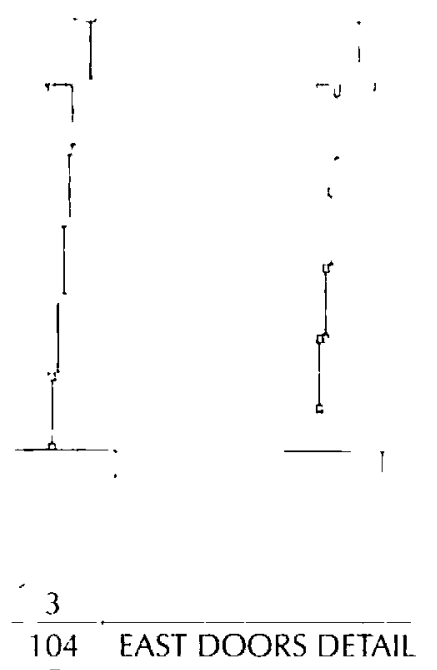

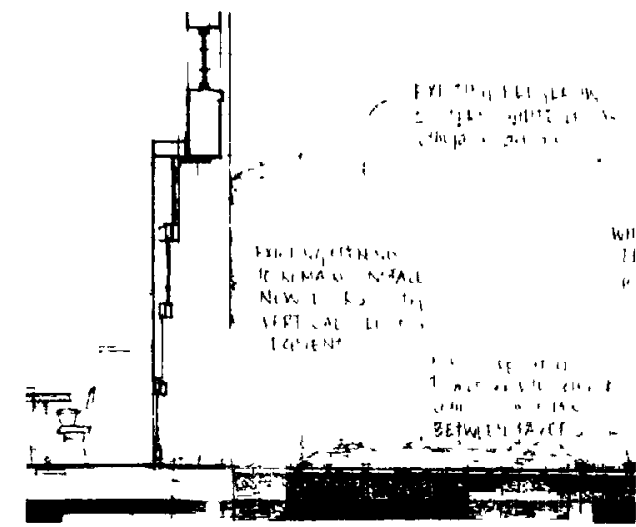

The air varies in different regions, at different seasons of the year, and even different hours of the day. The odorous, fresh sea-breezes are distinct from the fitful breezes along river banks, which are humid and freighted with inland smells. The bracing, light, dry air of the mountains can never be mistaken for the pungent salt air of the ocean. The air of winter is dense, hard, compressed. In the spring it has new vitality. It is light. mobile, and laden with a thousand palpitating odours from earth, grass, and sprouting leaves. The air of midsummer is dense, saturated, or dry and burning, as if it came from a furnace. When a cool breeze brushes the sultry stillness, it brings fewer odours than in May, and frequently the odour of a coming tempest. The avalanche of coolness which sweeps through the low hanging air bears little resemblance to the stinging coolness of winter.

The rain of winter is raw, without odour, and dismal. The rain of spring is brisk, fragrant, charged with life-giving warmth. I welcome it delightedly as it visits the earth, enriches the streams, waters the hills abundantly, makes the furrows soft with showers for the seed, elicits a pertume which I cannot breathe deep enough. Spring rain is beautiful, impartial, lovable. With pearly drops it washes every leaf on tree and bush, ministers equally to salutary herbs and noxious growths, searches out every living thing that needs its beneficence. 


\begin{tabular}{llr} 
Division C & Resource Library & C $[105]$ \\
\hline
\end{tabular}

\section{[ 105 ] RESOURCE LIBRARY}

\section{BOOK CASES}

$\checkmark$ Shelving units to be constructed from high quality maple or birch wood, dimensions as indicated in Drawings.

- The smell of books itself is enough to define the odor of this zone. The familiar and comforting smell of old books is a widely held observation and is frequently commented upon.
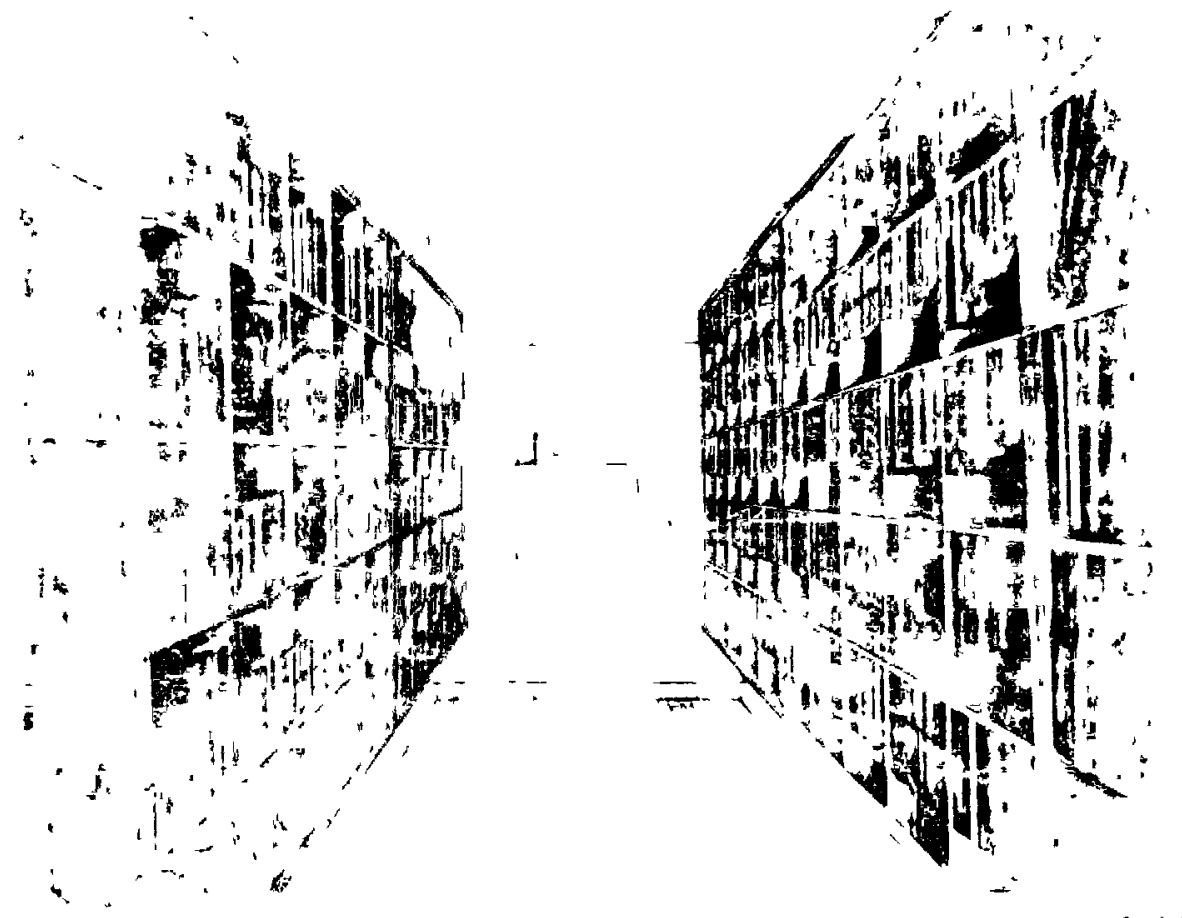

RESOLIRCE. IIRRAR!'

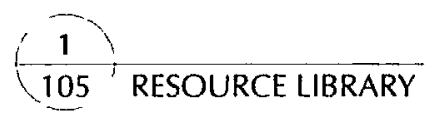

"Generations of boys and girls have been thoroughly familiar with the 'school room smell' which attaches itself to that wooden chalk rail with a wet sponge on it, the lockers loaded with raincoats, and the lunchkit, itself scented by the food it contains. Books read between smelly high school library cases have olfactory accents which remain emotionally associated with these early experiences in literature."

Richard Neutra, "The Sound and Smell of Architecture," Progressive Architecture, November 194966 


\section{[ 106 ] COFFEE ROOM}

\section{MILLWORK}

$\checkmark$ The countertop in the Coffee Room to be made from torrefied (smoked) maple, finished with three (3) coats, no-odor food-grade oil.

$\checkmark$ First person in the office to brew morning coffee. Afternoon "coffee breaks" to be scheduled for 2:00 pm daily.

\section{FLOORING}

$\diamond$ Sand and refinish existing flooring in kitchen and meeting room.

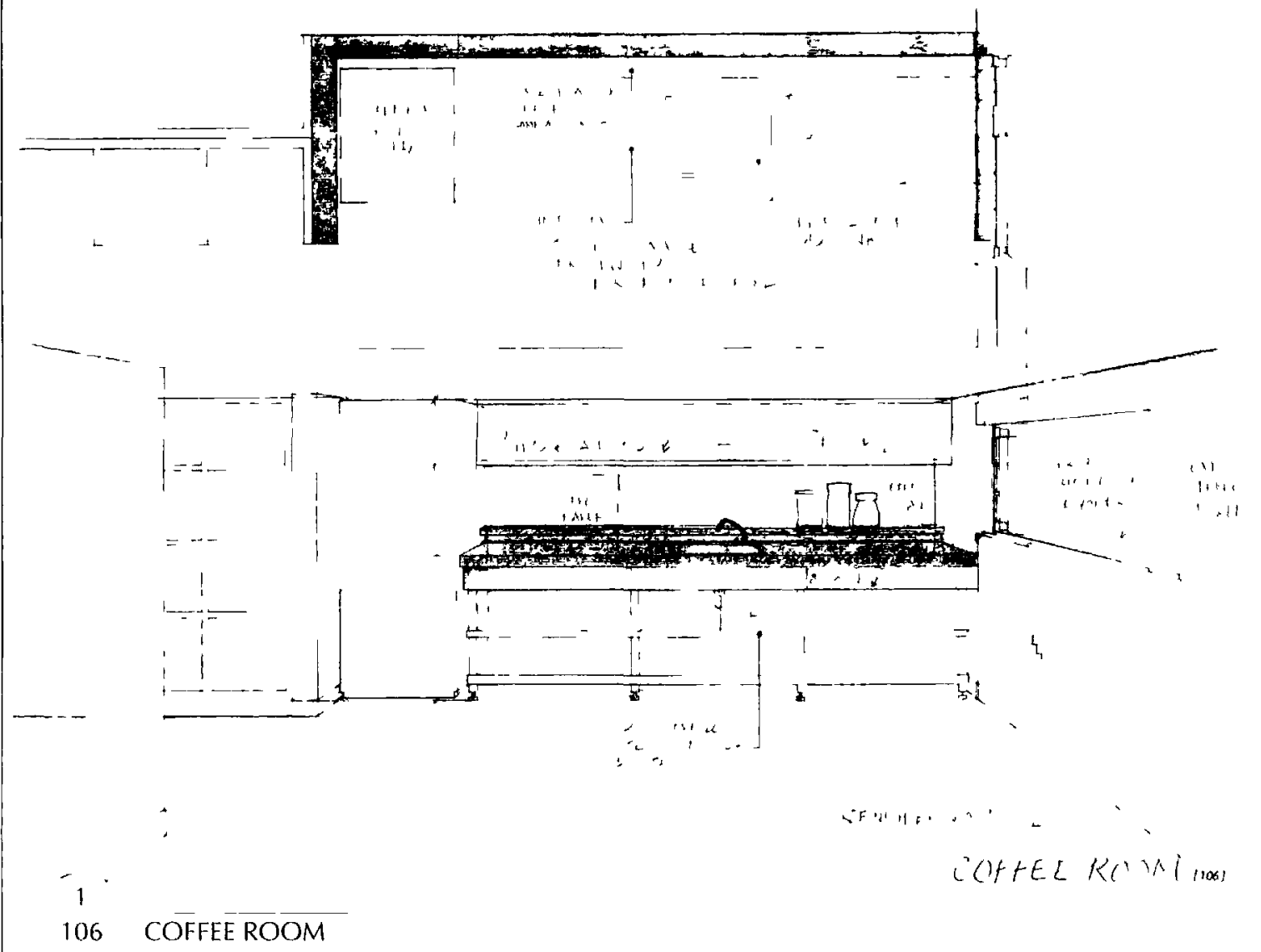

"Coffee is so much the smell and taste of morning for us now, that it is odd to think that, before its advent, beer was the common breakfast drink in Europe."

Constance Classen David Howes and Anthony Synot Aroma The cutural history of smoll, 68 


\section{[ 109 ] REAR ENTRY}

\section{FLOOR COVERING}

$\checkmark$ Rubber-bottomed, natural fibre (coir) woven floor mat for removal of snow/rain and excess dirt or mud from shoes prior to entering the office.

\section{COAT CLOSET AND BIKE STORAGE}

$\diamond$ Located near the rear entry, the coat closet will store hard hats, measuring tapes, and employees' steel-toe boots. For those who cycle to work, bicycle can be stowed in adjacent vertical bike storage closet. The coat closet and bike storage are concealed behind two 6 -foot sliding doors made of aromatic cedar. At the end of the workday, when the coat is removed from the closet one notices that it has become infused with the sweet, resinous scent of the cedar panels.

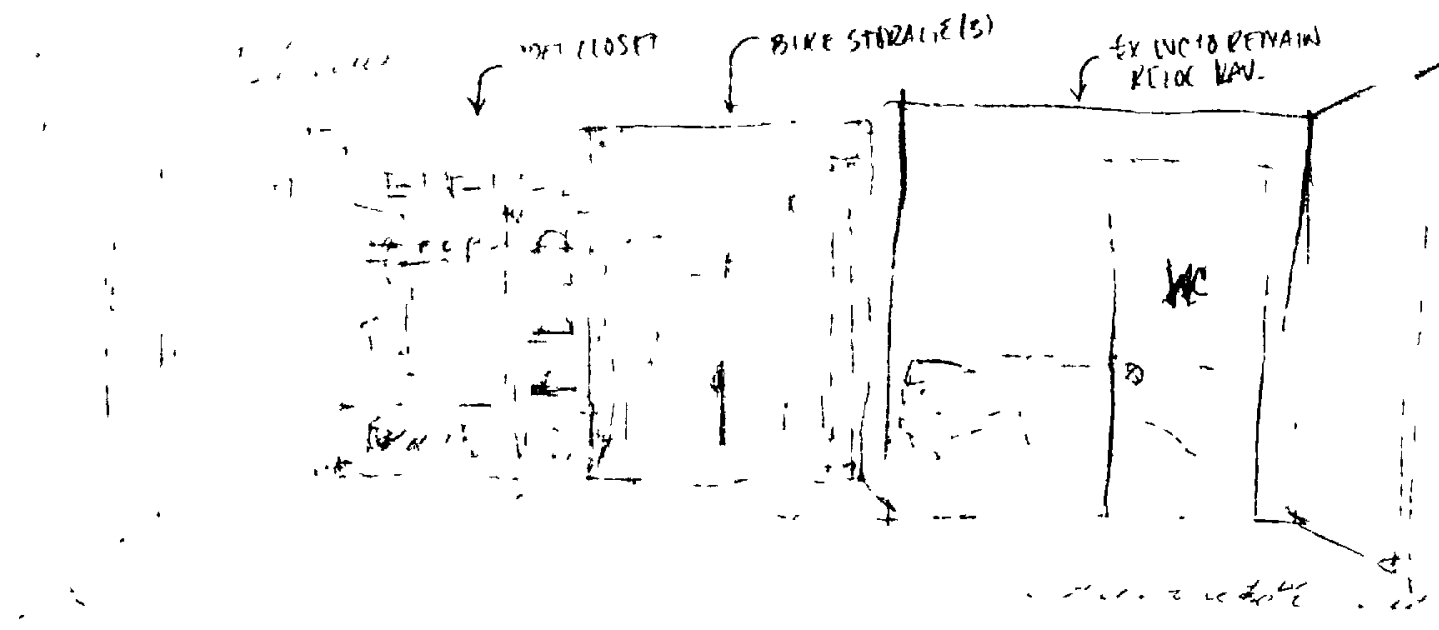




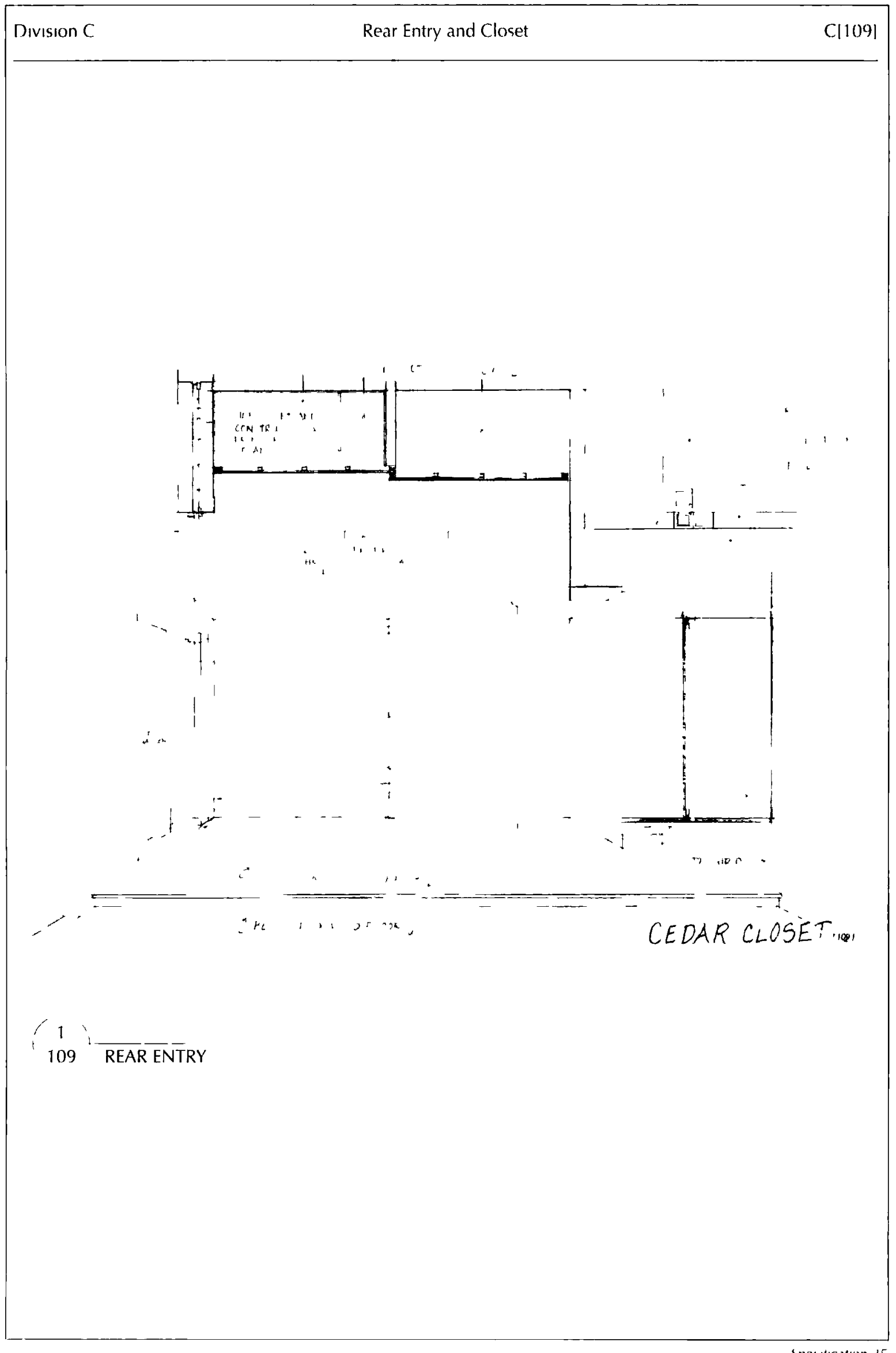




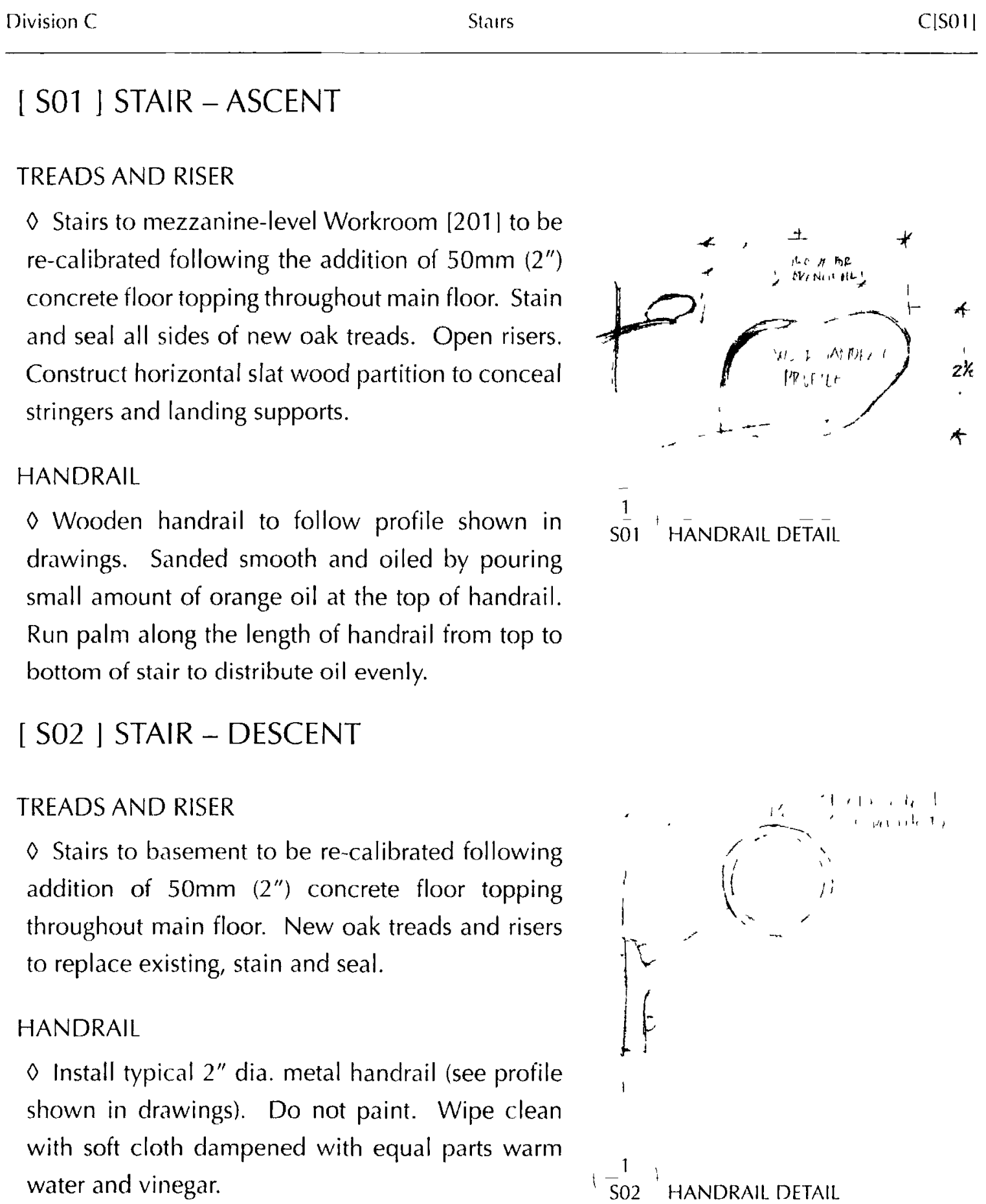

I S01 ] STAIR - ASCENT

\section{TREADS AND RISER}

$\checkmark$ Stairs to mezzanine-level Workroom [201] to be re-calibrated following the addition of $50 \mathrm{~mm}\left(2^{\prime \prime}\right)$ concrete floor topping throughout main floor. Stain and seal all sides of new oak treads. Open risers. Construct horizontal slat wood partition to conceal stringers and landing supports.

\section{HANDRAIL}

$\checkmark$ Wooden handrail to follow profile shown in drawings. Sanded smooth and oiled by pouring small amount of orange oil at the top of handrail. Run palm along the length of handrail from top to bottom of stair to distribute oil evenly.

\section{[ S02 ] STAIR - DESCENT}

\section{TREADS AND RISER}

$\checkmark$ Stairs to basement to be re-calibrated following addition of $50 \mathrm{~mm}\left(2^{\prime \prime}\right)$ concrete floor topping throughout main floor. New oak treads and risers to replace existing, stain and seal.

\section{HANDRAIL}

○ Install typical 2" dia. metal handrail (see profile shown in drawings). Do not paint. Wipe clean with soft cloth dampened with equal parts warm water and vinegar. 
This Project Stunks 62

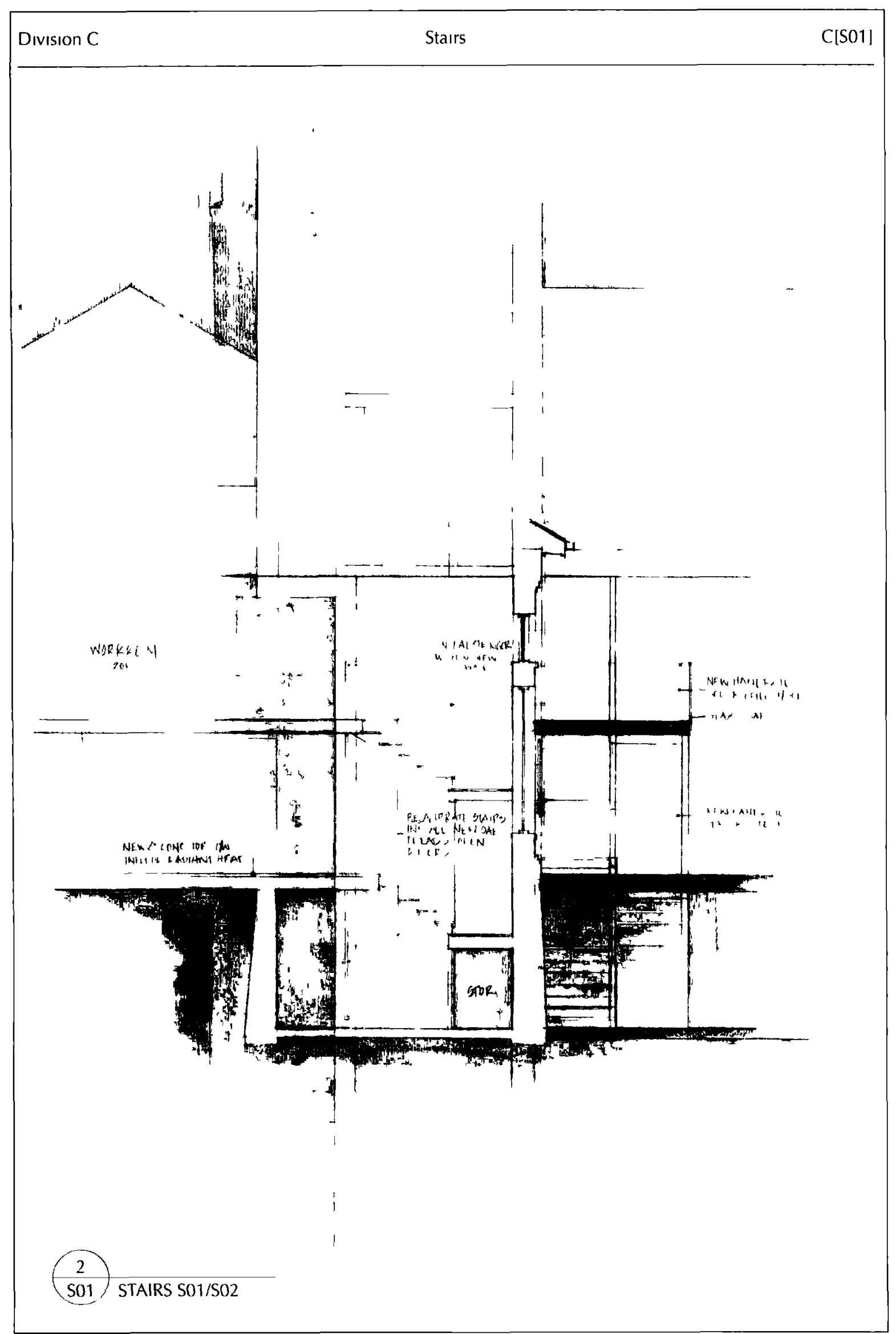





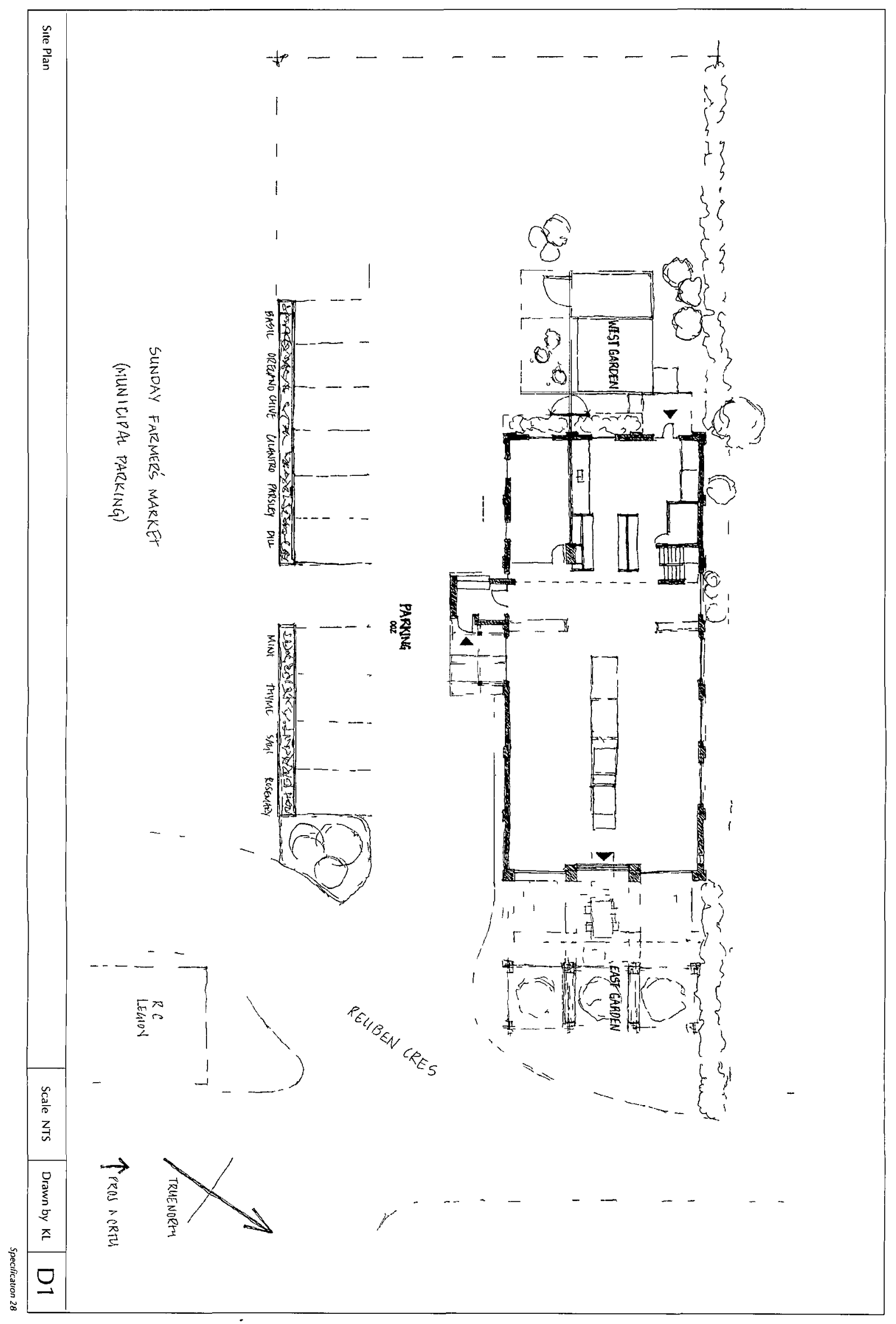

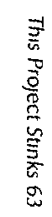



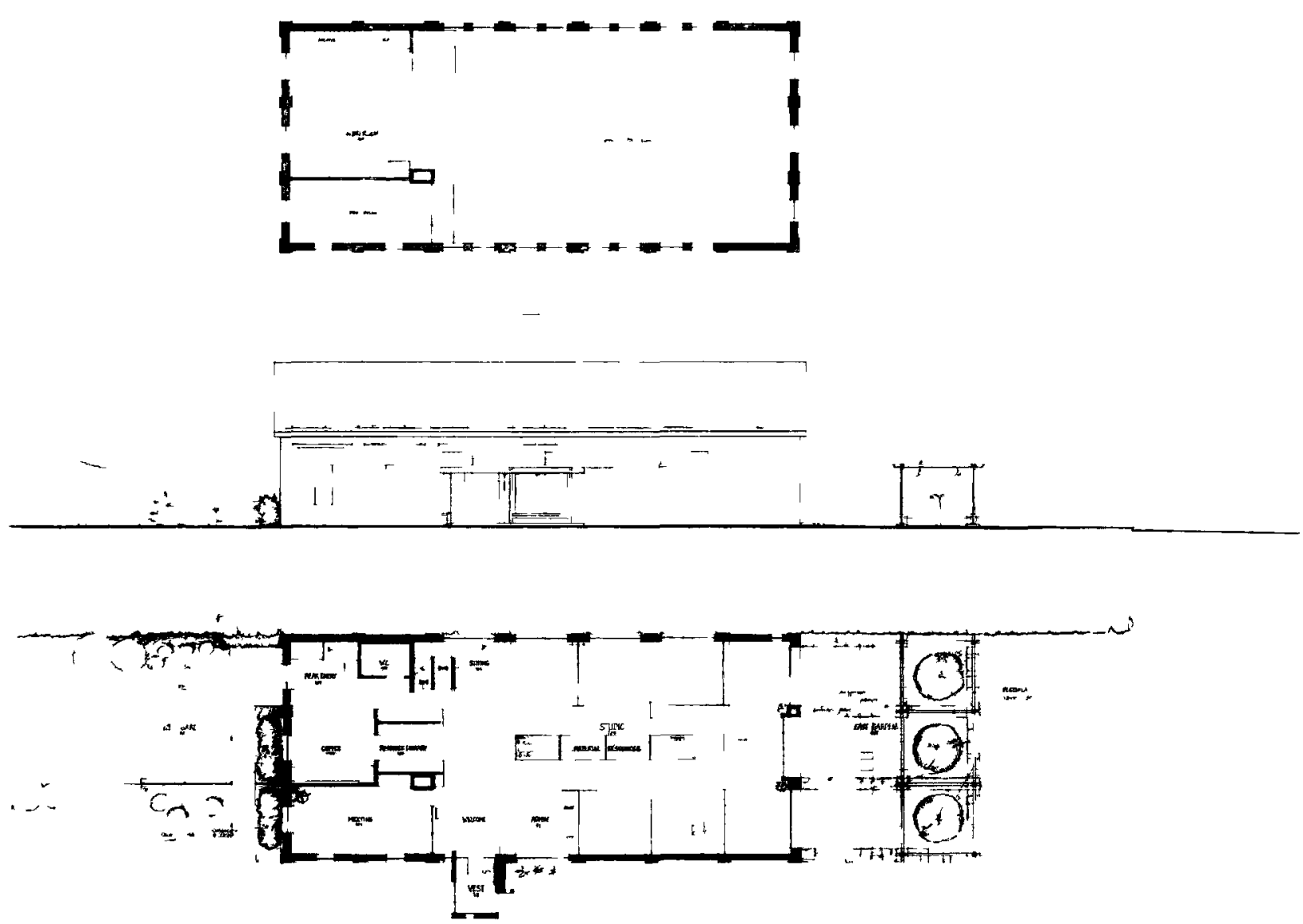


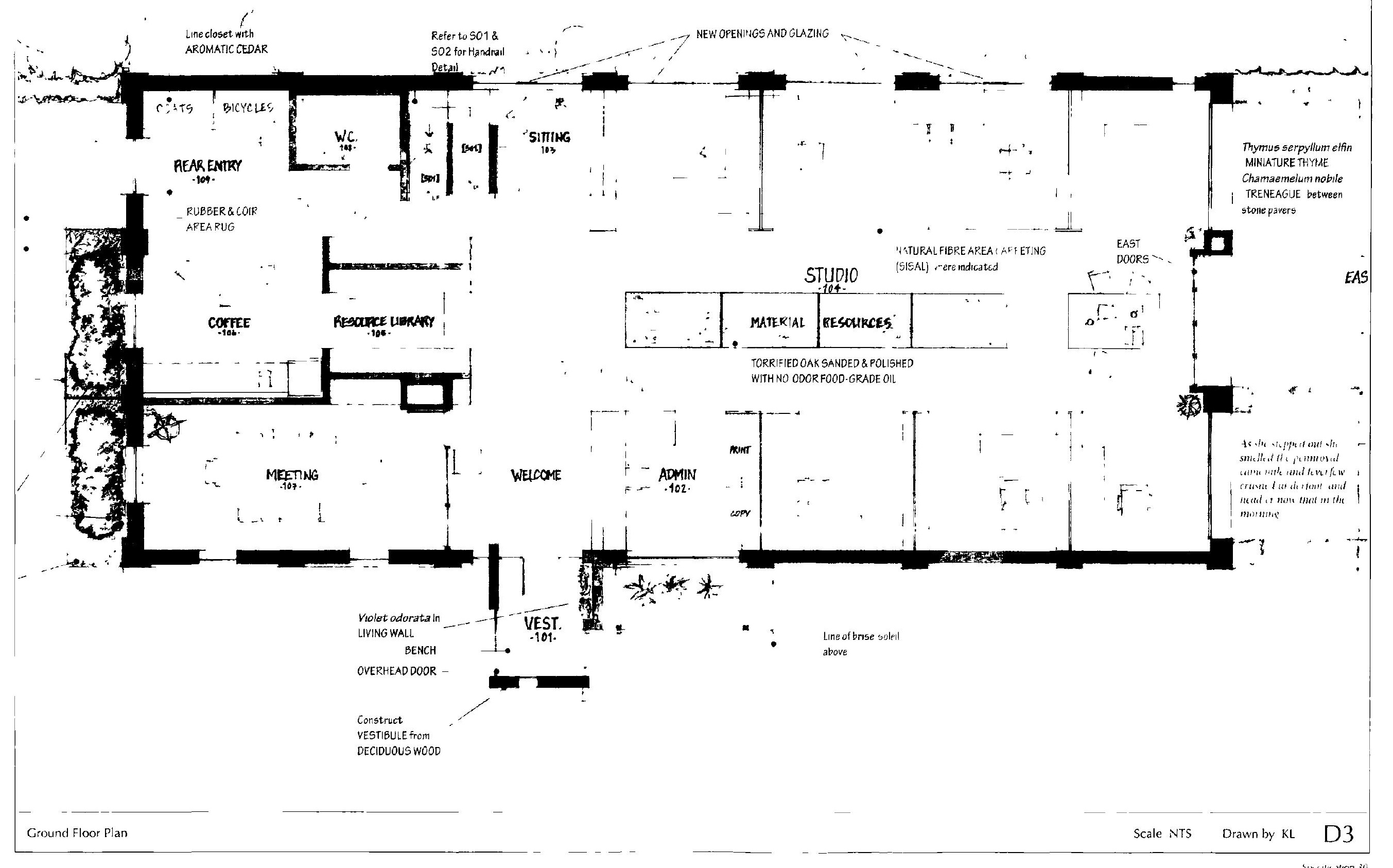




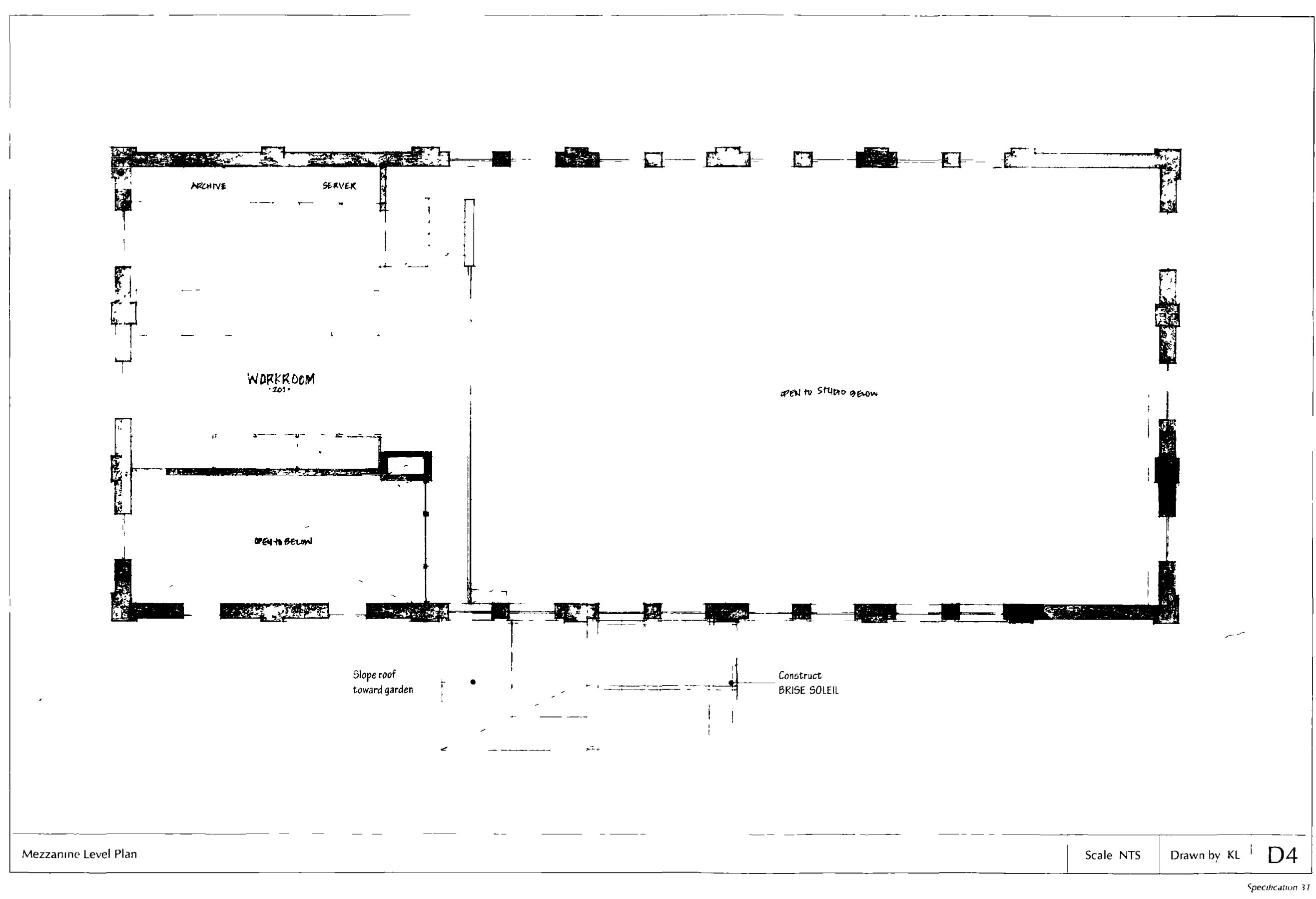




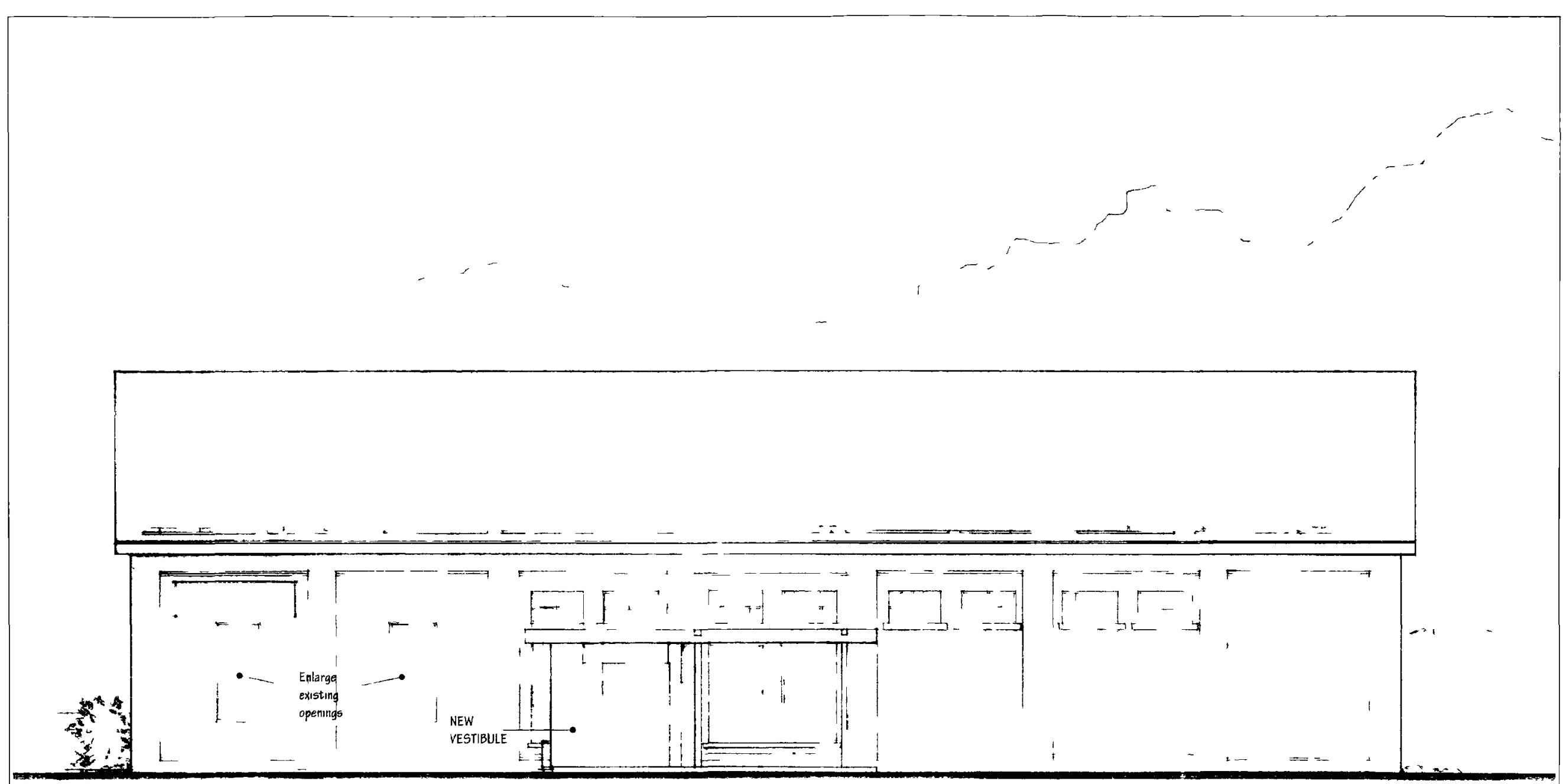




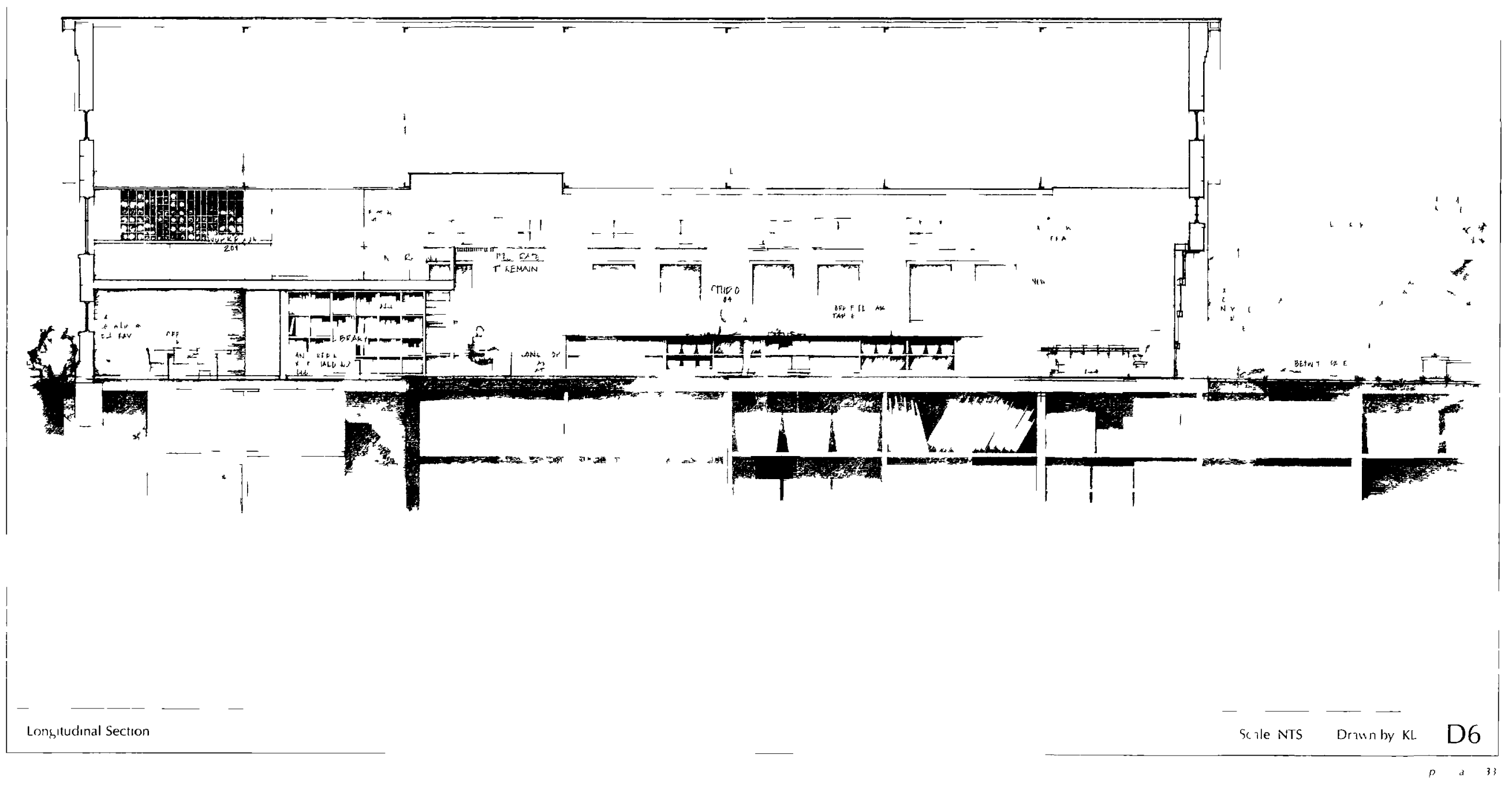




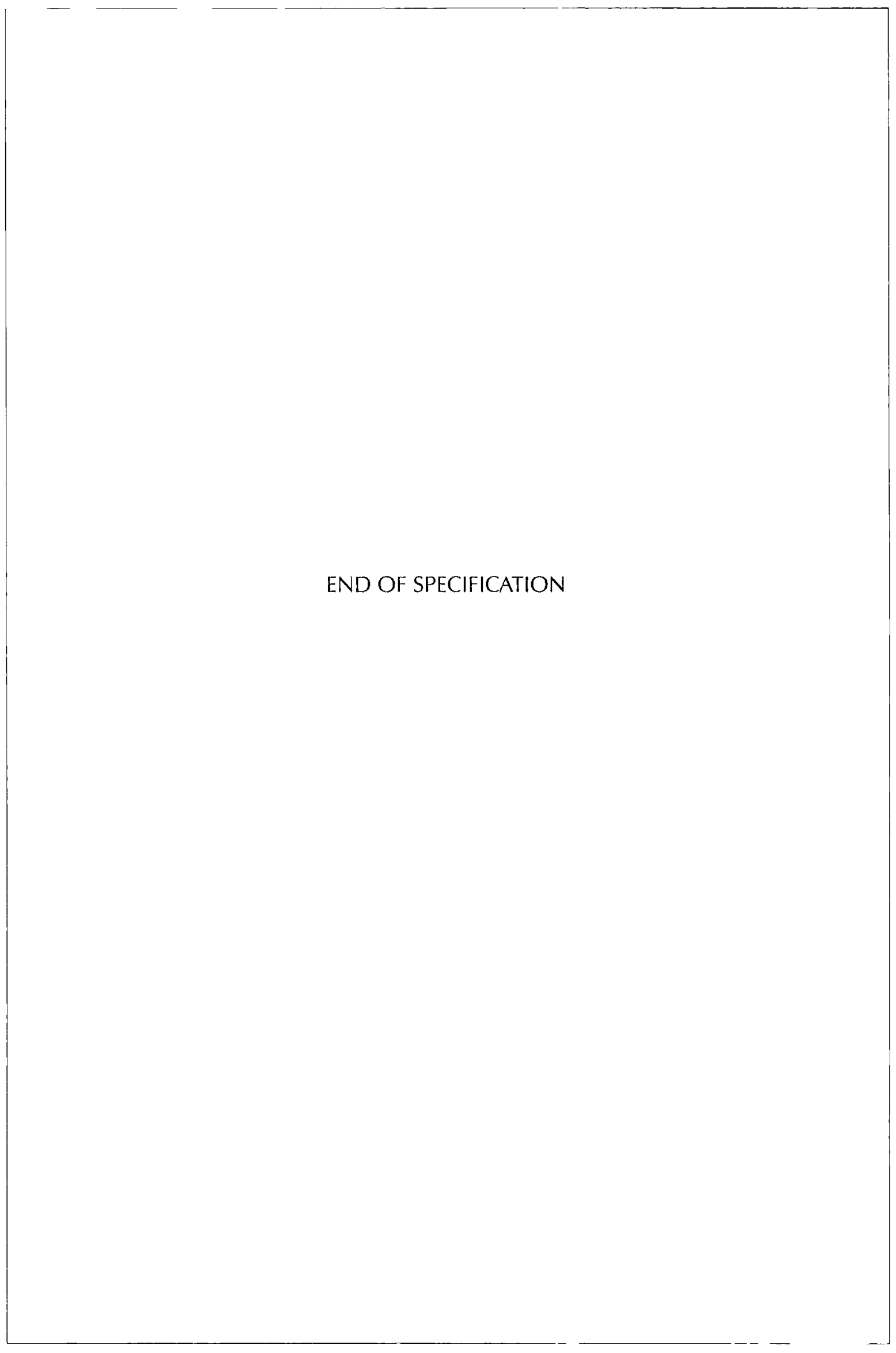




\section{Conclusion}

\section{Coming to Our Senses}

The goal of this thesis was to recover consciousness of the invisible dimension of architecture that enriches the experience of place. The sense of smell is essential to our existence and yet is rarely a consideration of architecture. This typical disposition toward odor in architecture is indicated in Seema Malik's study "More Than Meets the Eye." She states, "The olfactory sense though important, cannot always be considered in building design." ${ }^{1}$ Listing the olfactory among the superficial "Skin Senses" she limits the usability of the sense of smell to programming tasks (such as locating where smellier rooms should be within a building). This view--which fails to consider the factors that this thesis maintains give value to smell in architecture-represents the characteristic ignorance that has led to the present condition of architectural anosmia. This figurative "coming to our senses" also implies a literal returning to the senses, specifically the sense of smell, in the conception and design of architecture.

The multi-layered Project of Architecture tackles both designing with scent in mind and the issue of representing the intangible. Through the design of the Office for Architects, smelly details were incorporated into the architecture, without artificially fragrancing spaces or defaulting to 'scratch-n-sniff' features. In this way the inherent scent of materials within the design of the workplace infiltrate the subconscious to subtly remind the architects of

1 Seema Malik, "More Than Meets the Eye," in Blindness and the Multi-Sensorial City, eds. Patrick Devlieger, Frank Renders, Hubert Froyen and Kristel Wildiers (Philadelphia: Garant/Coronet Books, 2006) 178. 
its presence. Based on the theory discussed in Chapter 2 "Invisible and Indescribable", the Specification provides a framework to present the invisible, sensual qualities of the architecture in conjunction with a condensed version of the typical information contained in a Specification. The modification of the traditional format permits the Specification to include text, drawings and other images to detail the particulars. It is my hope that the Specification is received as a point of inspiration as well as a vehicle to re-engage a sensual way of thinking about, constructing and detailing architectural space.

Making visible the invisible is a challenge in its own right. This Project Stinks does not propose a concrete solution to this issue but provides a possible way for architectural representation to include the oft forgotten qualitative aspects of architecture. Hopefully, with the suggestion of a new way to do this smell can avoid further degradation by its reintegration into the practice of architecture. 


\section{List of Figures}

Figure 1. Rosewater

Source ship//www ehom co uh/hom_2323532 make-triple-rose-water him/s (Accessed 7 Ociober 2009)

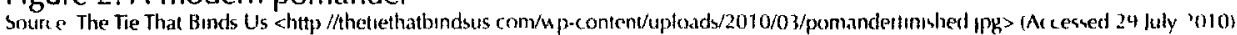

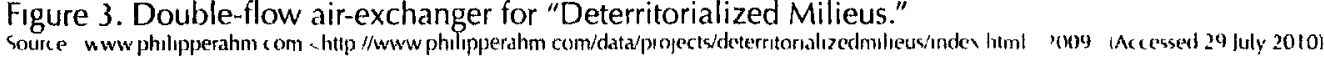

Figure 4. Pine Cone Garden by West 8.

Figure 5. City on Fire/City in Bloom in Rotterdam, by West 8.

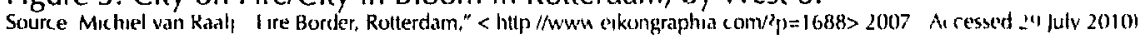

Figure 6. Irish Pavilion " $\mathrm{N}$ " by Tom dePaor Architects.

Figure 7. View from inside " $\mathrm{N}^{3 \prime}$ by Tom dePaor Architects.

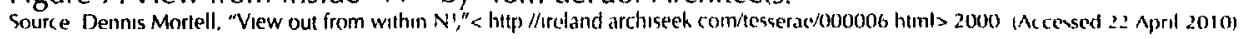

Figure 8. Sissel Tolaas and re_searchLab's "NASALO" dictionary as wall art, featured at the Liverpool Biennale in 2006.

Suurce "mac-tastic," "Sissel Tolaas @ IACT, Liverpool Biennal," < hitp //www filckr com/photos/mac-tastici308802805/> 14 Novemher 2006 (Accesced 2y /uly 20101

Figure 9. "Invisible Boy," a poem and illustration by Shel Silverstein.

Figure 10. Plan of Finnish Pavilion

Figure 11. Birch grove of Finnish pavilion

Figure 12. Southwest elevation of Kemptville Fire Hall with section overlay

Figure 14. The Kemptville Armoury prior to 1933 fire. 


\section{List of Drawings}

(1/001) Paver Detai

Kated a I U , क 2010?

(2/001) Pergola Detail

46

(3/001) East Garden Plan Detal

46

(4/001) Pergola Plan Detail

16

Katelvn Luc in 2010

hallelyn I una 2010

(2/001) Pergola Detail

(3/001) East Garden Plan Detail

(4/001) Pergola Plan Detail

Kalcelyn I ucas 2011

(5/001) East Garden

(2/002) Plan Detail with Perspective Sketch showing Parking and Herb Garden 48

hath kn! un w 2010

hate finl ut as 2010

(2/003) West Garden

(1/101) Partial Elevation

(2/101) Partial Plan

(3/101) Vestibule

katelsn Luc as 2010

hatehn Lut as 2010

$(2 / 10+4)$ Studio Plan

\begin{tabular}{l} 
(3/104) East Doors Detail \\
\hline 6060
\end{tabular}

(1/105) Resource Library 
(1/106) Coffee Room

Katelyn Lucas 2010

(1/109) Rear Entry

Katelyn Lucas 2010

(1/S01) Handrail Detail

(1/S02) Handrail Detail

Katelyn Lue.ss 2010

Stair S07/S02

(D1) Site Plan

(D2) Ground Floor Plan - Southwest Elevation - Mezzanine Level Plan

(D3) Ground Floor Plan

(D4) Mezzanine Level Plan

(D5) Southwest Elevation

(D6) Longitudinal Section 


\section{References}

Aamodt, Mette "Architecture smells' In Immaterial/ultramaterial architecture, dengnn, and materials, edited by Toshıko Moı New York George Brazıller, Inc and Harvard Design School, 2002

Ackerman Diane "Smell" In A Natural History of the Senses New York Random House, 1990

Axel, Richard "The Molecular Logic of Smell" scientific Americ an Special Edition, Secrets of the Senses, 2006 , $68-75$

Barbara, Anna, and Anthony Peiliss Imusible Aichitecture Expenencing Places through the Senso of Smell Milan Skıra Editore, 2006

Boyle, Sheryl and Marco Frascarı "Architectural Amnesia and Architectural Smell " Whitecture and Ideas (kelly Crossman) IX (2009) 36-47

Calvino, Italo Under the laguar Sun Translated by William Weaver Toronto Harcourt, Inc 1986

Canada's History Places Branoton Aımoury May 2010 http //www lreuxpatrimonuaux ca/visil-visite/altichagedısplay aspx? $1 \mathrm{~d}=9726$ \&page $=0$ (accessed May 29, 2010)

Cappon, Daniel 'The Anatomy of Intuition What's your Intuition Quotient?" Psychology Today, Mav/June 1993

Centre for Social Innovation $2010 \mathrm{http} /$ /social innovation ca/ (acc essed luly 21, 2010)

- Emergence The Story of the Centre tor Social Imnowation Report, Foronto Centre Ior Social Innovation, 2010

- Rigour How-To Create World (hanging Spaces Report, Toronto Centre for Soc ial Innovation, 2010

Classen, Constance Worlds of Sense Exploring the sense in history and across culturus New York Routledge 1993

Classen, Constance David Howes, and Anthony Synott Aloma The cultural hrstory of mell New York Routledge, 1994

Corbin, Alain The Foul and the Fragant Odor and the French social Imagination (ambridge, MA Harvard University Press, 1986

Cresswell, Julia "aesthetic" Oxford Dictionary of Word Ongins (Mord University Press hitp//www oxtordreterence $\mathrm{com} / \mathrm{v}$ lews/ENTRY html's subview=Main\&entry=t292 (103 (accessed August 13, 2010)

Damian, Peter, and Kate Damıan "Environmental Fragrano Ing" In The Smell Culture Reader, edited by Jim Drobnick New York Berg, 2006 
Phılıppe Rahm Architectes Detemitoralized Mileus 2010 http /www philpperahm com/data/projects/ deterritoralizedmilieus/ındex html (accessed June 15, 2010)

Dickinson + Hicks Architects Inc Specific ation for Addition to Cedarviewv Evangelistic Centre Orangeville, ON May 8, 2009

Drobnıck, Jım, ed The Smell Culture Reader New York Berg, 2006

Drobnick, Jım “Toposmıa Ait, Scent and Interıogatıons of Spatialıty Angelakı 7, no 1(2002) 3147

el Khoury, Rodolphe Polısh and Deodorize Paving the City in I ate Eighteenth-Century France In The Smell Culture Reader, edıted by Jım Drobnick, 18-28 New York Berg, 2006

Ingen, Trygg Odoı Sensatıon and Memoly New York Praeger, 1991

Filler, Martın Extra sensory perceptions" Progressive Architecture, April 19788285

rlamme-Jasper, Martına Architektur Architecture EXPO2000 Hannoter Outtildern Hatje (antz Verlag, 2000)

Torty, Adrian "Language and Drawıng" In Words and Buildings A Vocabulary of Modern Aichitecture, 29.42 Thames \& Hudson, 2004

Gerrard, Phil Re 25 Reuben Crescent Report, Planning \& Bulding Former Town of Kemptulle Muntip ility of North Grenville 2010

Gissen David Subnature Architectures Other Environments New York Princeton Architectural Press, 2009

Harrowsmith Country Life Singing the Blues' August 200956

Harrowsmith Country Life “Take Your Pick' August 200965

Keller, Helen The World I Live In London The Century Co , 1904, 1908

Koza, Brian J, Anna Cilmi, Melissa Dolese, and Debra A Zellner Color Enhances Orthonas al Oltactory Intensity and Reduces Retronasal Olfactory Intensity Research Publication Dept of Psychology, Montc laır State University, Oxford University Press, 2005

Kulp Ashley 'Council holds firm on tate of surplus buildings despite concens Irom committer Kemptrille $E M C$, July 1,2010

- "NG sets plan in motion to deal with surplus buildings" kemptw/le EMK, August '7, 2009

- "Old firehall to receive heritage designatıon' kemptville EMK, July 1, 2010

Levin, David Michael "Decline and Fall" In Modernity and the Ifegemom of Vision, edited by David Micharel Levin, 186-217 Los Angeles University of Calitornta, 1993

- "Introduction In Modernity and the Hegemony of Vision edited by David Michad l evin I os Angeles University of Californı Press, 1993

Lloyd Thomas, Katie "Specifications writıng materials in architecture and philouophy" $1 R Q, 2004277283$

MFS "Two Houses by Charles Moore Archtectural Record, June 1977109116 
Malık, Seema "More Than Meets the Eye" In Blındness and the Multu Sensorial Citv, edited by Patrick Devlıeger, Frank Renders, Hubert Froyen and Kristel Wildıers, 177-201 Phıladelphia Guant/Comonet Books, 2006

Malnar, Joyce, and Frank Vodvarka Sensory Design Minneapolıs, MN Unıeraty of Minnesota Press, 2004 Marlın, Willıam, ed Nature Neaı late essays of Rıchard Neutra Santa Barbara, CA Capra Piess, 1989 Neutra, Richard Buildings and Projects (192; 50) Vol 13 vols New York Frederick A Praeger, 1966

- Buldings and Projects (1950 60) Vol 23 vols New York Froderick A Prieger, 19591966

- Nalure Near late essays of Richard Neutia Santa Barbara, ( A Capra Press, 1989)

- "The Sound and Smell of Architecture" Progressive Architecture, November 19.4965-66

Otero-Pailos, Jorge "An Olfactory Reconstruction of Philip Johnson \& Glass House" 11 Files 57, 200840 4)-15

O'Toole, Shane "Tom de Paor N^3, Vence Architecture Biennale Archiseeh lieland luly 2000 http//ıreland archiscek com/tesserae/000006 html (accessed April 22, 2010)

Pallasmad, Juhanı "An Architecure of the Seven Senses' In Questions of Perception Phenomenology in Architecture, by Steven Holl, Juhanı Pallasmaa and Alberto Perez Gomez, 2737 Japan Architecture and Urbanısm, 1994

- "Hapticity and Time" THte Architectural Review, May 2000

Participants Finland $2000 \mathrm{http} / /$ www expo2000 de/expo2000/index e htm (accessed April '010)

"Pine Cone Garden" West 8 Urban Design and Landscape Architecture http //www west8 nl/projects/gardens/ pine_cone_garden/ (accessed April 22, 2010)

Plant Encyclopedia http //www backyardgardener com/plantname/Index html (accessed July ?010)

Porteous, I Douglas "Smellscape" Progress in Physkal Crography 9, no 3 (September 1985) 336378

Quantrill, Malcolm Reima Pietha Architecture, Context and Modernsm New York Rizzolı, 1985

Rahm, Philippe "Inhalable Spaces Aitbram org May 2005 http //www artbram org/mhialable-spac ca/ (accessed June 30,2010$)$

Rushton, Susie "The Sweat Hog" The New York Times Newspaper nytımes com August 27, 2006

Suskind, Patrick Pertume The Story of a Murderer New York Vintage Boohs 1986,

Sabine "Sabsi" "Finland at Expo 2000" a Hinland Travel Page Virtual Tourist September 14, 200.2 http //members virtualtourist com/m/tt/5637/ (accessed April 2010)

Sacks, Oliver The Man Who Mistook His Wife for a Hat New York I larperPerennal, 1990)

Schildt, Goran Alvar Aalto masterwolks New York Universe Publıshıng, 1998

Silverstern, Shel "Invisible Boy' In Where the Sidewalk [nds, 82 New York HarperCollins 1996

smell " Merriam-Webster Online Dictionary $2010 \mathrm{http} / /$ www merriam-webster com/dic tionary/smell cac c essed 
April 22, 2010).

The World of Flowers. Gifting inc . 2010. http://www.theflowerexpert.com/filowers (ac c ('sed July 1, 2010$).$

Torréfaction, MEC. Wood Torrefaction. 2005. http://www.mectorrefaction.com/index.html lac c cssed May 2010$)$.

Turin, Luca. "The Science of Scent." TED.com. 2005. http://www.ted.com/talks/lang/eng/luca_turin_on_the science_of_scent.html (accessed February 8, 2010).

—. The Secret of Scent London: Faber and Faber Limited, 2006.

van Raalj, Michiel. Fire, by West 8 . July 25, 2007. http://www.eikongraphici.com/?p=1688 (accessed July 14 , 2010).

Weschler, Lawrence. Mr. Wilson's Cabinet of Wonder. New York: Vintage Books, 1996.

Zumthor, Peter. Thinking Architecture. Second, expanded. Boston: Birkhauser, 2006. 